\title{
Alluvial architecture of fluvio-deltaic successions: a review with special reference to Holocene settings
}

\author{
M.J.P. Gouw \\ Department of Physical Geography, Faculty of Geosciences, Utrecht University, P.0. Box 80115, 3508 TC Utrecht, the Netherlands. \\ Email:marc.gouw@tno.nl
}

Manuscript received: March 2006; accepted: August 2007

\begin{abstract}
Alluvial architecture has been subject of many studies because of the occurrence of natural resources in ancient fluvial successions. This paper provides an overview of the current state of research on alluvial architecture with special reference to Holocene fluvio-deltaic settings. Several examples from modern fluvio-deltaic areas, especially the Holocene Rhine-Meuse delta (the Netherlands) and the Lower Mississippi Valley (U.S.A.), are used to illustrate the architectural elements that can be distinguished in fluvial successions and to show the influence of the various controls on alluvial architecture (base level, climate, tectonism, aggradation, avulsion, and compaction). Avulsion is regarded as a principal process in the formation of fluvio-deltaic sequences, because it determines the location and number of active channels on the floodplain. The avulsion mechanism is still subject of debate, though. A brief description of the evolution of process-based alluvial-architecture models is given. These models simulate the proportion and distribution of coarse-grained channel belts in fine-grained overbank deposits. The major drawback of the present-day alluvial-architecture models is the lack of (three-dimensional) quantitative field data to test and validate them. The paper concludes with the suggestion to collect more architectural data from natural fluvial settings, to improve simulation of channel-belt geometry in alluvial-architecture models, and to implement new data and knowledge of fluvial processes into models.
\end{abstract}

Keywords: alluvial-architecture models, architectural elements, avulsion, fluvial stratigraphy, Lower Mississippi Valley, Rhine-Meuse delta

\section{Introduction}

Alluvial architecture can be defined as the geometry, proportion and spatial distribution of different types of fluvial deposits in the alluvial succession (Leeder, 1978; Allen, 1978). In the past decades, the architecture of fluvial successions received much attention because of its practical significance, i.e. the occurrence of natural resources (oil, gas, water, metals) in ancient sedimentary successions of fluvial origin (e.g. Ryseth \& Ramm, 1996; Tye et al., 1999). Alluvial-architecture studies include quantitative characterizations of the architecture of fluvial sequences (e.g. Ryseth et al., 1998; Bridge et al., 2000), explorations of the relationships between (changing) controls and resultant fluvial stratigraphy (e.g. Shanley \& McCabe, 1993; Heller \& Paola, 1996; Ashworth et al., 2004, 2007), and simulation of alluvial architecture through modelling (e.g. Bridge \& Mackey, 1993a; Mackey \& Bridge, 1995; Karssenberg \& Bridge, in review). Knowledge of the alluvial architecture and its controls leads to a better understanding of the evolution of fluvial systems.

This paper presents an overview of the research on alluvial architecture of fluvio-deltaic systems, with special reference to the Holocene Rhine-Meuse delta (the Netherlands) and the Lower Mississippi Valley (U.S.A.). These areas are two of the most extensively studied fluvial areas in the world and can be regarded as modern analogues for ancient fluvio-deltaic systems. The following subjects are addressed: 1) the architectural elements of fluvial successions; 2) the controls on alluvial architecture; and 3) the history of process-based alluvialarchitecture modelling. The paper concludes with some suggestions for future alluvial-architecture research. 


\section{Architectural elements}

Three major architectural elements can be distinguished in fluvio-deltaic successions: relatively coarse-grained channelbelt deposits, fine-grained overbank deposits, and organics (Fig. 1).

\section{Channel-belt deposits}

Channel-belt deposits in aggrading alluvial successions occur as sand bodies encased in fine-grained deposits and organics (e.g. Fisk, 1944, 1947; Allen, 1964, 1965; Berendsen, 1982; Smith et al., 1989; Nadon, 1994; Törnqvist, 1994; Törnqvist et al., 1996; Farrell, 2001; Makaske et al., 2002). Sandy and gravelly channel-belt sediments result from deposition of coarse-grained material in the river-bed. The geometrical properties of a channel-belt sand body (henceforth referred to as channel belt) can be characterised by the ratio between its width $(w)$ and thickness $(t)$ : the width/thickness ratio $(w / t)$. The $w / t$ of a channel belt is related to: 1 ) the degree of lateral and vertical accretion of the channel; and 2) the scouring depth of the channel. The depth of scour of an active river channel determines the minimum thickness of its channel belt. The thickness of the channel belt increases as it aggrades vertically (Fig. 2a).

When subdividing river channels into three basic patterns (braided, meandering, and straight; Leopold \& Wolman, 1957; Allen, 1965; Schumm, 1968), a high $w / t$ is attributed to braided systems and a low $w / t$ to straight channels. Meandering river channels take an intermediate position. Hence, the $w / t$ of a

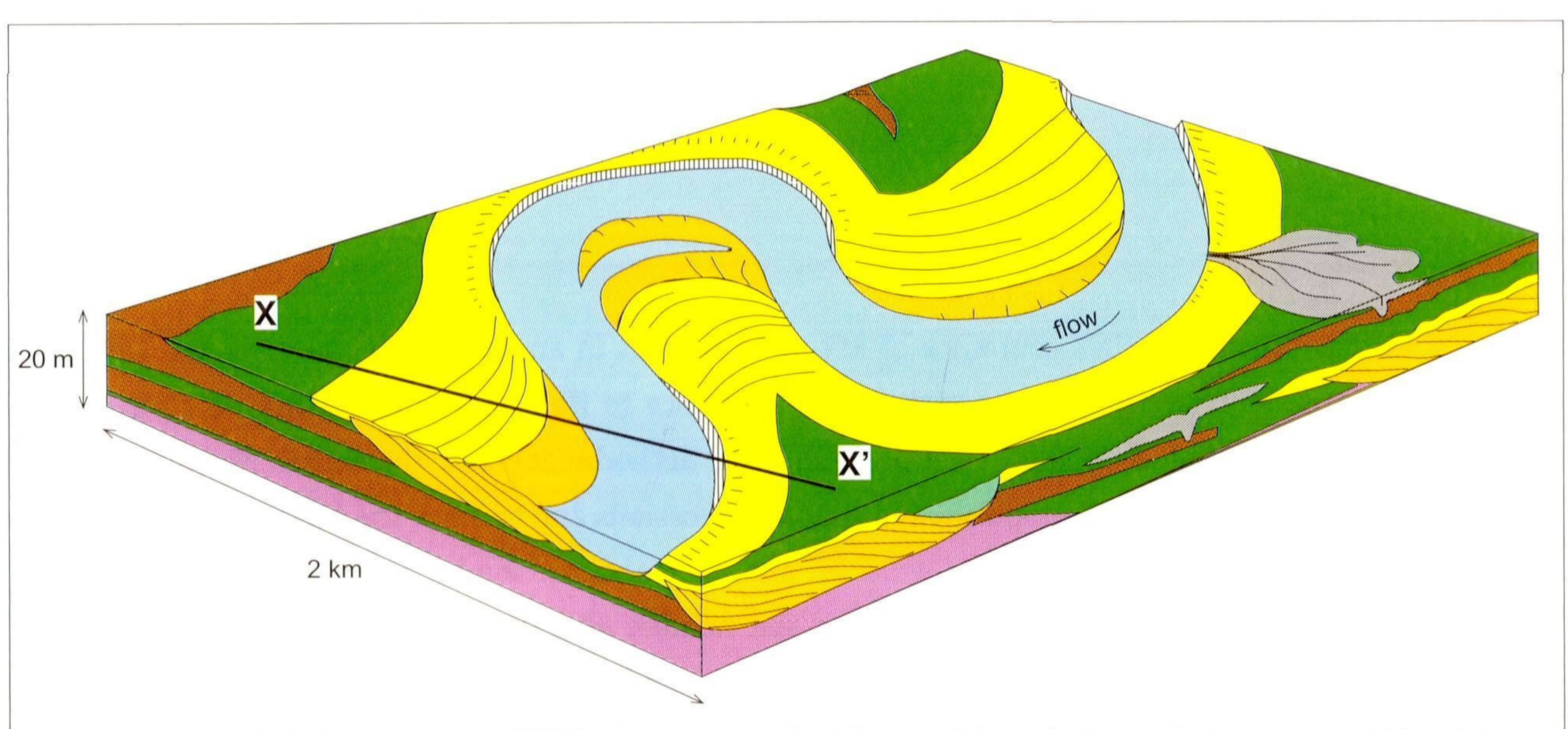

$a$.

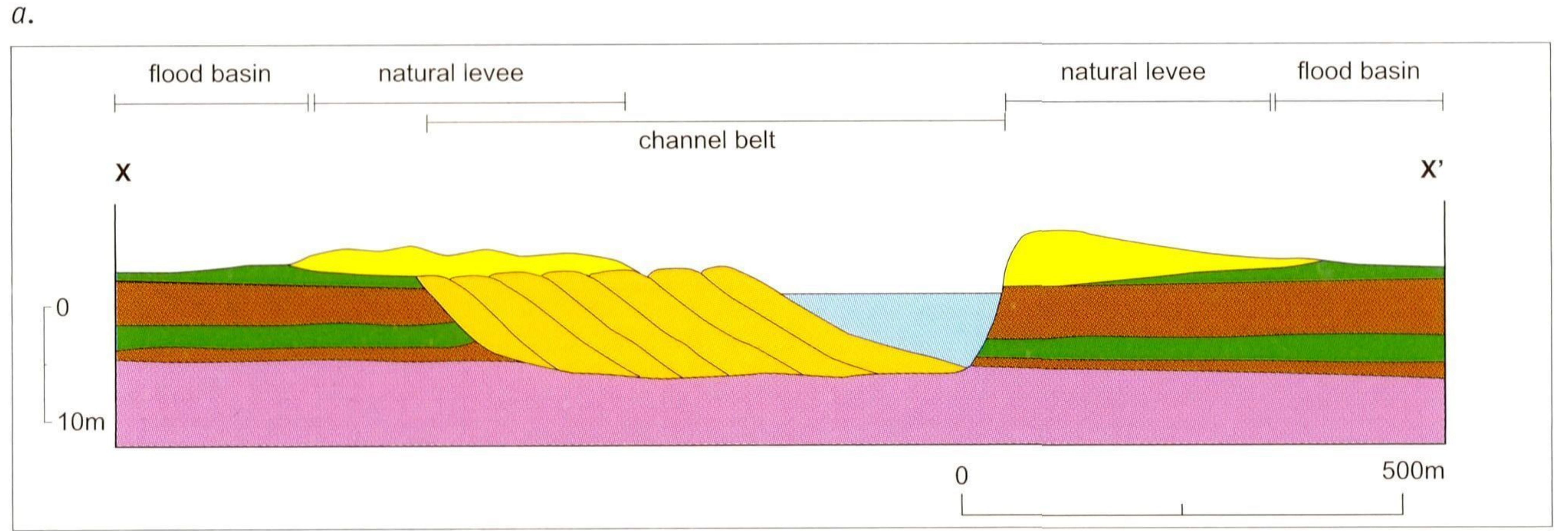

$b$.

LEGEND

channel-belt deposits (sand and gravel)

channel-fill deposits (clay)

natural levee deposits (sandy and silty clay)

crevasse-splay deposits (sand, sandy and silty clay, clay)

flood basin deposits (clay)

organics (peat)

substrate

escarpment

section $X-X$

\section{Architectural elements}

channel-belt deposits

overbank deposits

organics
Fig. 1. Block diagram (a) and cross-section (b) of a meandering river in the Holocene Rhine-Meuse delta (the Netherlands). The Holocene fluvio-deltaic succession comprises channel-belt deposits, overbank deposits, and organics (adapted from Weerts, 1996). 


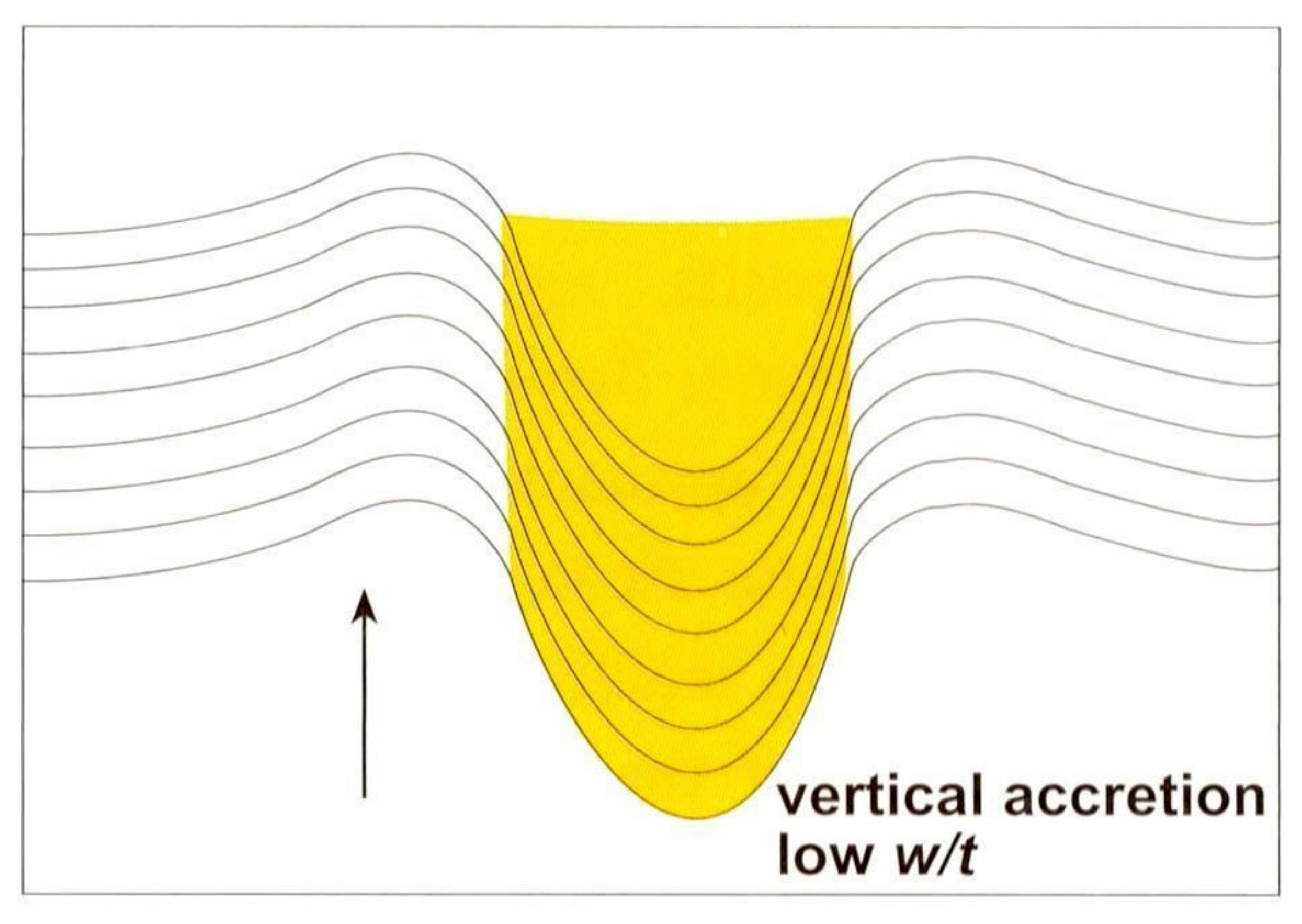

\section{LEGEND}

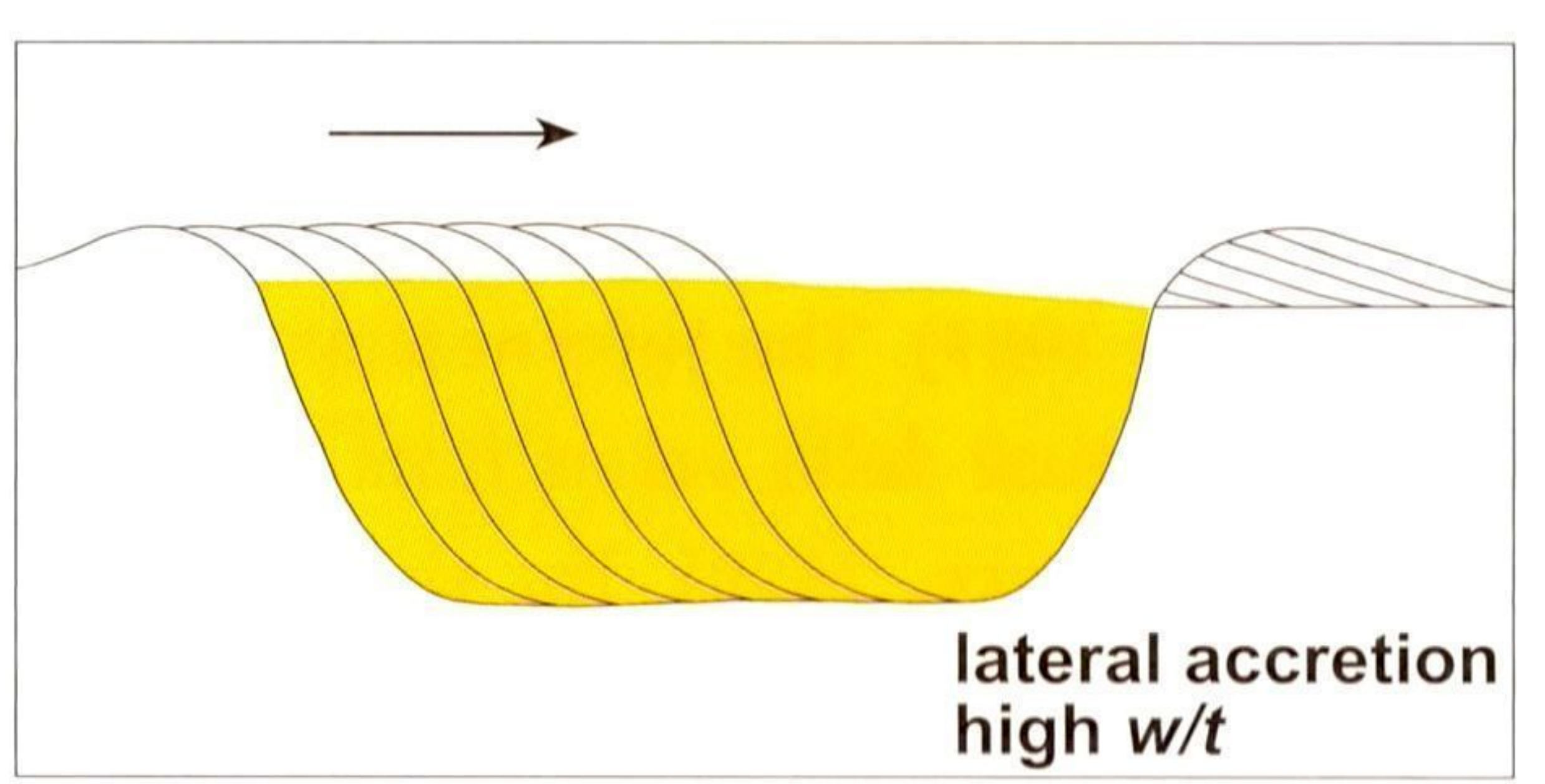

Fig. 2. Width/thickness ratio $(w / t)$ of channel belts as related to lateral and vertical accretion of the channel (after Makaske, 1998, 2001).

channel belt is related to the style of its formative channel, i.e. channel planform. The varying $w / t$ of straight and meandering rivers is a result of differences in the ability of the channel to migrate laterally (Fig. 2). Straight channels, often associated with anastomosing rivers (straight anastomosing cf. Makaske, 1998), are characterized by virtually no lateral migration. In aggrading settings, the lateral stability of straight channels in combination with vertical accretion within the active channel leads to narrow and thick channel belts (ribbons cf. Friend et al., 1979) (Fig. 2a). The $w / t$ of these ribbon channel belts commonly ranges from 5 to 15 (Friend et al., 1979; Friend, 1983; Gibling, 2006), although some workers classified channel belts with a maximum $w / t$ of 30 as ribbons (e.g. Nadon, 1994). Lateral accretion of meandering channels leads to wide channel belts (Fig. 2b). In the vast dataset compiled by Gibling (2006), channel belts formed by meandering channels are up to $15,000 \mathrm{~m}$ wide. The $w / t$ of these channel belts is relatively high. For the Rhine-Meuse delta, Weerts (1996) reported $w / t$ values of 20 to up to 500 for channel belts formed by meandering channels.

Changes in channel planform may occur in case of successive river systems (e.g. Fisk, 1944; Törnqvist, 1993b; Aslan \& Autin, 1999; Berendsen \& Stouthamer, 2000; Aslan et al., 2005) or alongstream a single channel system. Examples of the latter case are the lower Rhine in the Netherlands (Wolfert, 2001), the lower Mississippi River in the U.S.A. (Schumm et al., 1994), and the Brahmaputra River in Bangladesh (Bridge, 2003, p. 150). Törnqvist et al. (1993), Makaske (1998), Makaske et al. (2007), and Gouw \& Berendsen (2007) reported significant $w / t$ decreases in a downstream direction of several Holocene channel belts in the Rhine-Meuse delta (Fig. 3). Similar alongstream variations in channel-belt geometry have been reported for the Lower Mississippi Valley (Fisk, 1944; Bridge, 1999; Gouw \& Berendsen,
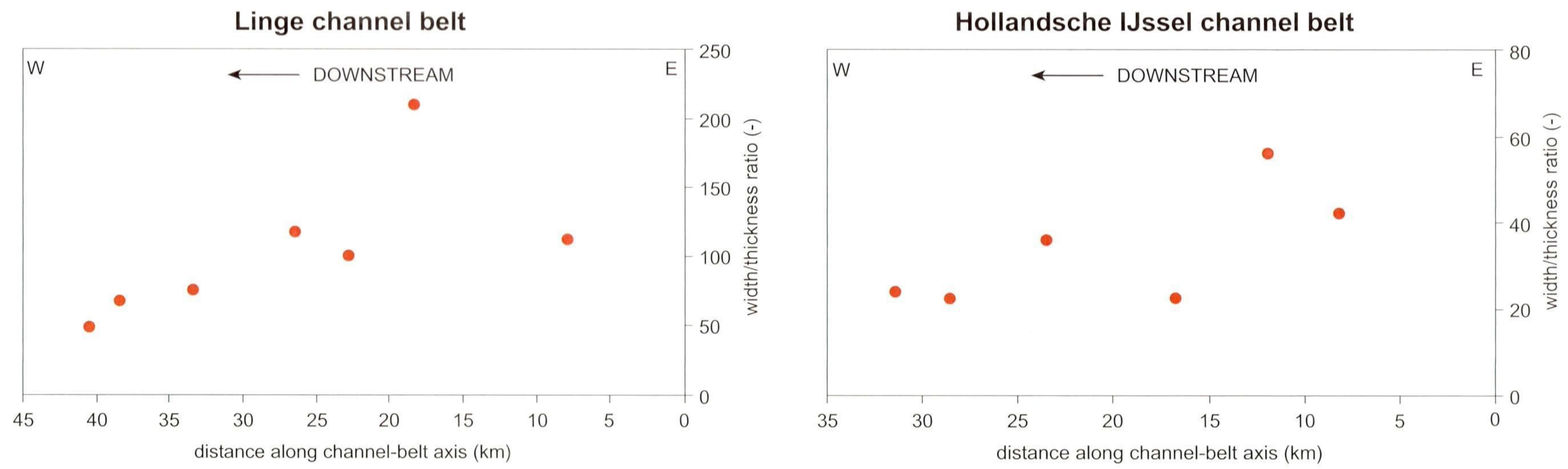

Schoonrewoerd channel belt

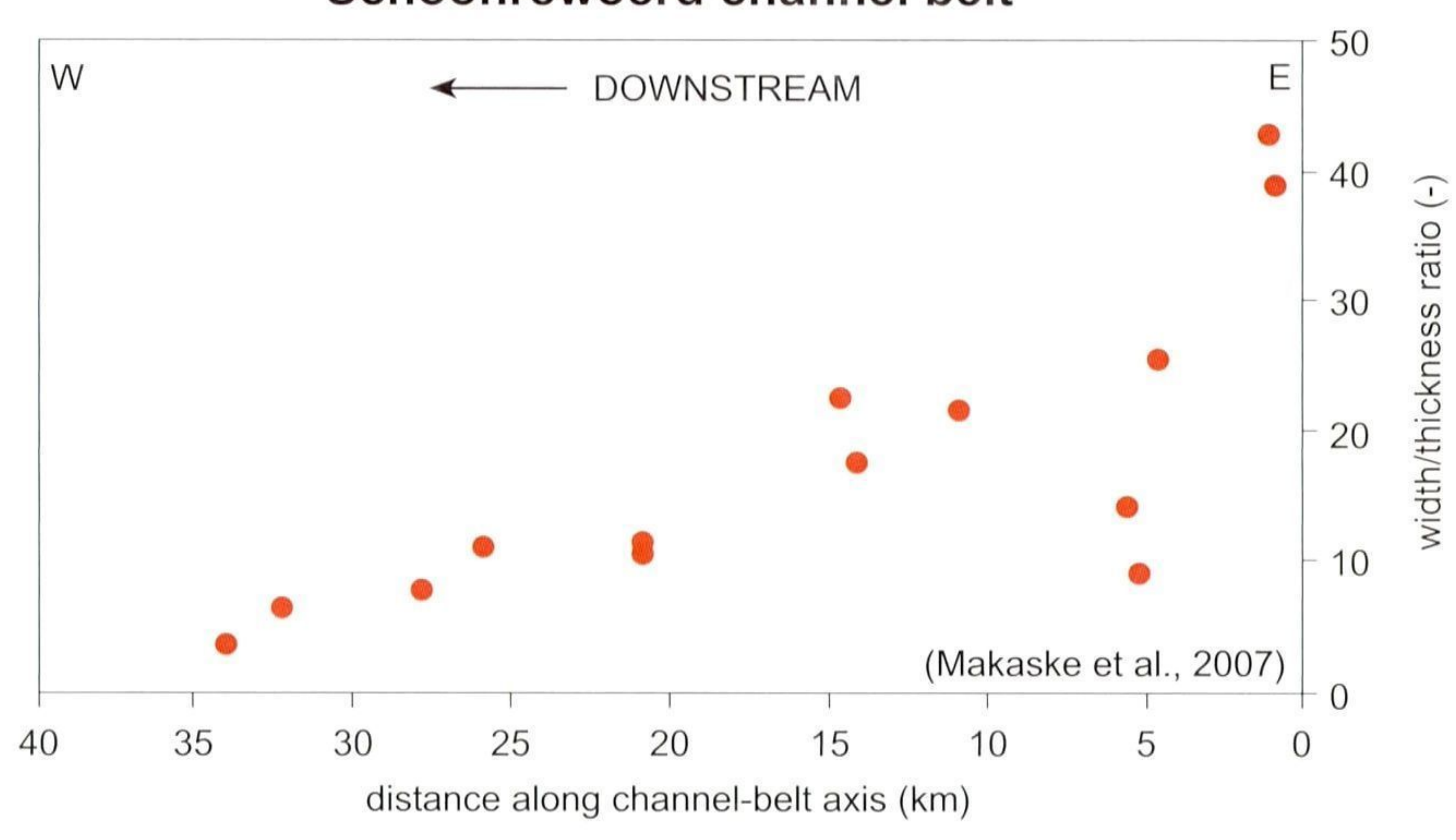

Schaik channel belt

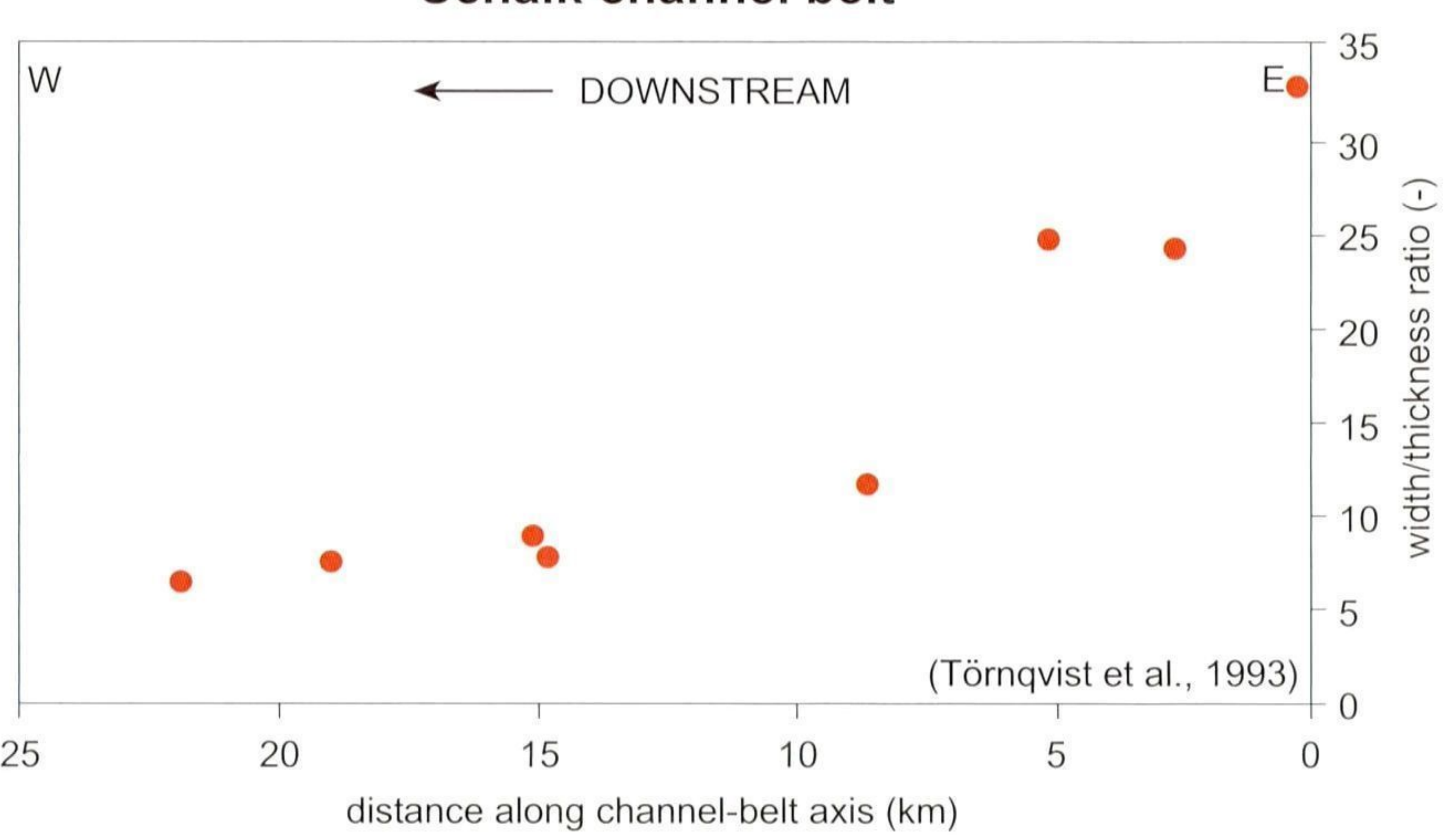

Fig. 3. Width/thickness ratios of four Rhine channel belts in the Holocene Rhine-Meuse delta (after Gouw \& Berendsen, 2007). Width/thickness ratios decrease by a factor 2.5 - 5 in a downstream direction. 
2007). The downstream decrease of channel-belt width and width/thickness ratio has been related to a longitudinal increase of bank stability and a decrease of stream power (Makaske, 1998; Gouw \& Berendsen, 2007). Downstream narrowing of channel belts may be accompanied by a changing architecture of overbank deposits (e.g. Törnqvist et al., 1993; Weerts \& Bierkens, 1993; Stouthamer, 2001a).

The proportion of channel-belt deposits in a single crosssection through an alluvial succession is referred to as channelbelt deposit density (Bridge \& Leeder, 1979) or channel-belt deposit proportion CDP (Bridge \& Mackey, 1993a, 1993b; Mackey \& Bridge, 1995). Here, CDP is used. It is defined as the area of channel-belt deposits relative to the total area of the alluvial succession in cross section (Bridge \& Mackey, 1993a, 1993b; Mackey \& Bridge, 1995). The CDP ranges from 0 (no channelbelt deposits) to 1 (the entire succession is composed of channel-belt deposits). Furthermore, vertical channel-belt deposit proportion (Bridge \& Mackey, 1993a) refers to the thickness of channel-belt deposits relative to the total thickness of the entire succession in a single vertical (for instance a core).

A fluvial sand body can be composed of several channel belts that are connected. The connectedness ratio $C R$ (Leeder, 1978; Bridge \& Mackey, 1993a, 1993b; Mackey \& Bridge, 1995) refers to the degree to which individual channel belts are connected. The $C R$ is defined as 'the length of horizontal contact between connected channel belts divided by the total horizontal width (or length) of channel-belt deposits in the transect' (Mackey \& Bridge, 1995, p. 14) and ranges from 0 (all channel belts are unconnected, thus isolated) to 1 (all channel belts are fully connected). CR, as used by for instance Mackey \& Bridge (1995), does not include vertical contact between the channel belts. $C D P$ and $C R$ depend on the ratio between channel-belt width and floodplain width, channel geometry, variation in deposition rate across the floodplain, avulsion (frequency), compaction, and tectonics (Leeder, 1978; Bridge \& Mackey, 1993b). In addition, Mackey \& Bridge (1995) mentioned distance from avulsion locations and cross-section orientation as factors affecting $C D P$ and $C R$ values.

\section{Overbank deposits}

Overbank deposits consist of relatively fine-grained sediments (clay and silt) deposited outside the river-bed during flood stages. When flooding occurs, sediment-laden water drops relatively coarse-grained overbank sediments (fine sand and silt) near the channel whereas fine-grained sediments (clay) are transported into the flood basin. As a result, fining of sediments with distance perpendicular to the flow direction occurs (e.g. Fisk, 1944; Allen, 1964; Berendsen, 1982; Törnqvist et al., 1996; Farrell, 2001; Makaske et al., 2002). Furthermore, overbank-deposit thickness decreases with distance from the channel (e.g. Fisk, 1944, 1947; Berendsen,
1982; Farrell, 2001; Törnqvist \& Bridge, 2002) (Fig. 4). 0verbank fines can be lithogenetically divided into natural levee deposits, flood basin deposits, and crevasse-splay deposits (e.g. Fisk, 1947; Allen, 1964; Berendsen, 1982). Of these, only the first two are 'true' overbank deposits in the sense of being formed by episodic flooding of the river channel. Crevasse-splay deposits are rapidly formed sediment bodies associated with breaching of the natural levee (e.g. Allen, 1964; Smith \& Pérez-Arlucea, 1994).

In the Rhine-Meuse delta, natural levee deposits occur 50 to $500 \mathrm{~m}$ alongside the (former) channel (Stouthamer, 2001b). Widths of well over $2000 \mathrm{~m}$ have been reported for the lower Mississippi River area (Farrell, 1987). The thickness of natural levee deposits in the Rhine-Meuse delta varies from $0.5 \mathrm{~m}$ to up to $5 \mathrm{~m}$ (Weerts, 1996; Makaske, 1998). For the southern Lower Mississippi Valley, thicknesses of more than 7.5 metres have been reported (Fisk, 1944, 1947).

Smith et al. (1989) have proposed a model of crevasseevolution based on their observations in the Saskatchewan River area, Cumberland Marshes (Canada) (Fig. 5). In the first stage (stage I splay), a sheet-like splay is formed in the flood basin with shallow, unstable channels quickly developing as
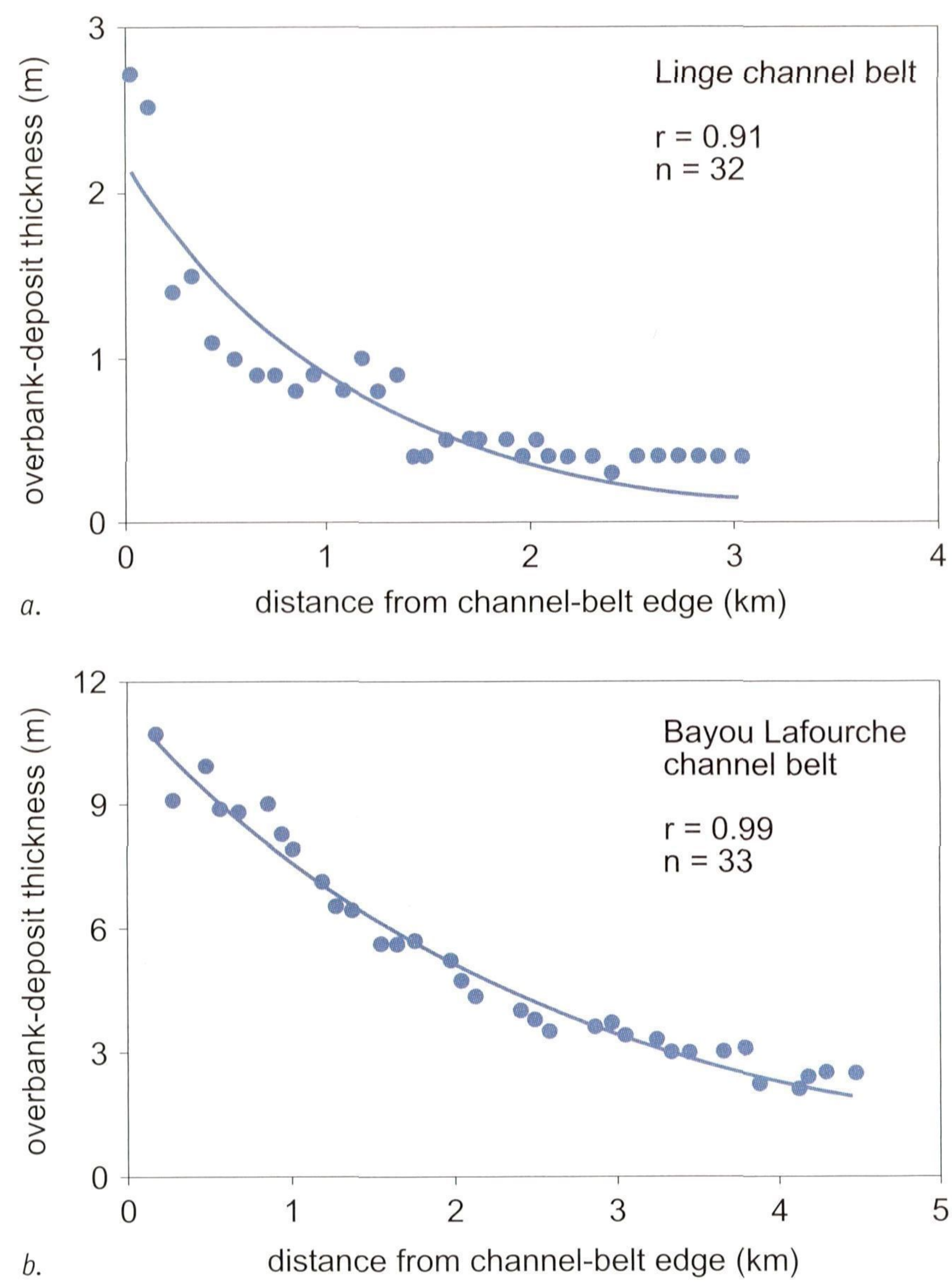

Fig. 4. Thickness of overbank deposits as a function of the distance from the channel-belt edge for a. the Linge channel belt (the Netherlands); and b. the Bayou Lafourche channel belt (USA). The regression analysis points to an exponential decrease of overbank-deposit thickness with distance from the channel-belt edge (Törnqvist \& Bridge, 2002). 


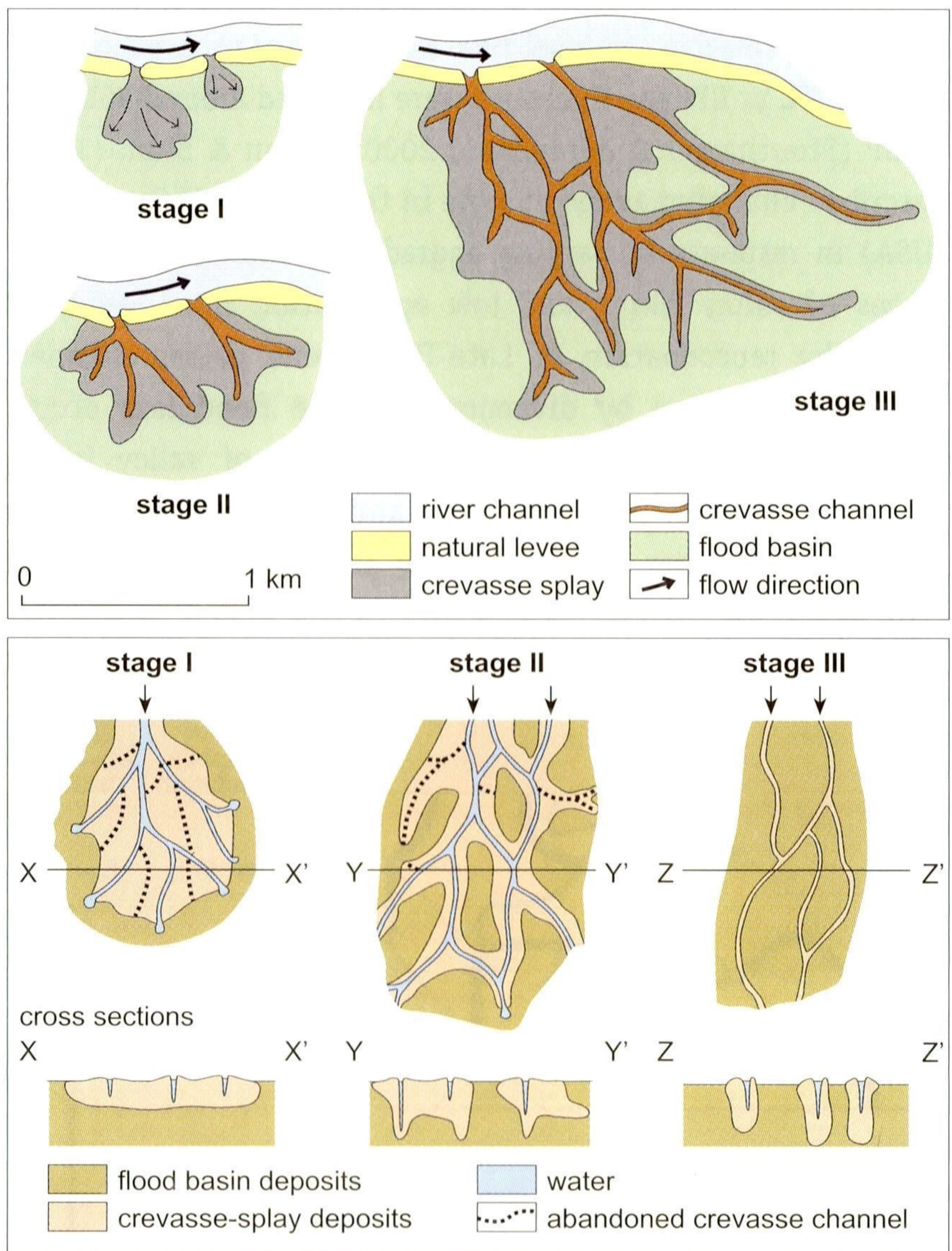

Fig. 5. Evolution and sedimentary products of crevasse splays (after Smith et al., 1989 in Stouthamer, 2001a). See text for explanation.

the splay becomes larger. In cross-section perpendicular to direction of progradation, this produces a lens-shaped body of silts and sands encased in flood basin deposits. Farrell (2001) showed that even a simple stage I splay is a complex landform and the splay sand body is just a small part (probably only $30 \%$ ) of the total crevasse complex. As the splay further develops, the channels become more stabilised and extension and rejoining of channels occur (stage II splay). This leads to sheet sand bodies and elongated forms surrounded by flood basin deposits. In stage III splays, flow is concentrated in a few stable channels, which enclose flood basins. This produces isolated ribbon sand bodies encased in clays and organics.

In the model of Smith et al. (1989), a new river course eventually evolves from a crevasse-splay complex. This way of avulsion results in a newly formed channel encased in largescale crevasse-splay deposits (avulsion belt cf. Smith et al., 1989). Avulsion belts are described for, amongst others, the Saskatchewan River (Smith et al., 1989; Smith \& Pérez-Arlucea, 1994; Pérez-Arlucea \& Smith, 1999; Farrell, 2001), the southern Lower Mississippi Valley (Aslan et al., 2005), and the RhineMeuse delta (Makaske, 1998; Stouthamer, 2001b; Makaske et al., 2007). Avulsion belts can cover an area of several tens (Stouthamer, 2001b) to several thousands (Aslan et al., 2005) of square kilometres. Therefore, avulsion-belt deposits may form a significant part of (ancient) alluvial successions (Smith et al., 1989; Smith \& Pérez-Arlucea, 1994; Farrell, 2001; Aslan et al., 2005; Makaske et al., 2007). Stouthamer (2001b), however, showed that an avulsion belt, at least in the RhineMeuse delta, does not always accompany avulsion sites. She gave two possible explanations for this. Firstly, the newly formed channel may have eroded the avulsion-belt deposits. In that case, only part of the original avulsion belt is preserved. Secondly, the avulsion belt may never have been formed. This seems to be the case when avulsion by channel reoccupation (cf. Aslan \& Blum, 1999) occurs. Channel reoccupation is a common mode of avulsion and has been recorded in both subrecent fluvial settings, such as the Rhine-Meuse delta (Stouthamer, 2005), the Saskatchewan River area (Morozova \& Smith, 1999), the Texas Gulf Plain (Aslan \& Blum, 1999), and the Lower Mississippi Valley (Aslan et al., 2005), as well as in ancient alluvial sequences (e.g. Mohrig et al., 2000).

\section{Organics}

Contrary to channel-belt and overbank deposits, organics are not part of a river system. Organic beds (peat, coal) are common in alluvial successions, though, because organics may be present in the flood basins adjacent to the channel belts. The organic component in fluvio-deltaic successions is formed by peat, mainly (e.g. Kolb \& Van Lopik, 1958; Berendsen, 1982; Törnqvist, 1993a; Saucier, 1994). Furthermore, organic lake deposits may occur (Van der Woude, 1984; Törnqvist, 1993a; Weerts, 1996). In the Rhine-Meuse and Mississippi River deltas, the proportion of organics tends to increase in a downstream direction (Berendsen \& Stouthamer, 2001; Törnqvist et al., 1996).

In general, the proportion of organic matter in the alluvial succession is inversely related to the deposition rate of clastic sediments (e.g. Morozova \& Smith, 2003): when clastic input is high, organic content is low, and vice versa. Formation of organic layers in the avulsion-controlled floodplain of the Saskatchewan River seems to be influenced by the location of the major active channels, and the location and relative elevation of ancient channel belts. When a channel belt is abandoned, it remains a high-standing feature (alluvial ridge) on the floodplain due to differential compaction. Parts of the floodplain are isolated from the influence of the active channel(s), which favours peat formation (Morozova \& Smith, 2003).

\section{Controls on alluvial architecture}

The architecture of fluvial sequences is a result of the complex interaction of external (allogenic) and internal (autogenic) controls acting upon river systems (e.g. Blum \& Törnqvist, 2000). Next, the following factors influencing alluvial architecture are discussed: sea level, climate, basin subsidence and tectonics, aggradation, avulsion, and compaction. 


\section{Sea level}

Fluvial systems respond to changing base level. In case of rivers at continental margins, sea level generally acts as the base level. Over the last 20,000 years, global eustatic sea-level rise occurred after the Last Glacial Maximum (LGM; 0xygen Isotope Stage 2), which influenced the evolution of deltas all over the world (Stanley \& Warne, 1994). The combined effect of eustatic sea-level rise and isostatic land-movement (subsidence/uplift) causes a relative change in sea level. In the Netherlands, a relative sea-level rise occurred during the Holocene (Jelgersma, 1961; Van de Plassche, 1982), which created accommodation space and net aggradation of fluviodeltaic sediments. Accommodation space is defined here as being the volume of space that can be filled with sediments within the present process regimes (cf. Blum \& Törnqvist, 2000). Over the Holocene, relative sea-level change determined whether or not accommodation space for fluvial sediments was created in the first place. The accommodation space that can be generated in a given time span is positively correlated to the rate of relative sea-level rise.

Fluvial style in deltas has been associated to changing rate of sea-level rise. Changing fluvial style is accompanied by changing sedimentation patterns and thus influences alluvial architecture. Törnqvist (1993b) showed that anastomosing rivers were present in the central part of the lower Rhine-Meuse delta during times of rapid sea-level rise (Middle Holocene). When the rate of sea-level rise decreased, the rivers changed to a meandering channel type. Similar changes in channel planform as related to the rate of sea-level rise have been reported for the lower Mississippi River (Aslan \& Autin, 1999). Makaske (1998, 2001), however, noted that low stream power promoted the development of the anastomosing system in the Rhine-Meuse delta and that rapid sea-level rise is not a necessary condition for anastomosis. Notwithstanding, rapid sea-level rise is considered as a favourable condition for the existence of laterally stable channels in the Holocene RhineMeuse delta (Törnqvist, 1993b; Törnqvist et al., 1993; Makaske, 1998, 2001).

Avulsion, defined as the sudden abandonment of a part or the whole of a channel belt in favour of a new course (Allen, 1965), determines the channel recurrence interval on the floodplain and thereby affects alluvial architecture (Leeder, 1978; Bridge \& Leeder, 1979; Bridge \& Mackey, 1993a; Mackey \& Bridge, 1995; Heller \& Paola, 1996). Stouthamer \& Berendsen (2000) showed that the first Holocene avulsions in the RhineMeuse delta occurred downstream from the boundary between net aggradation and incision, i.e. the inland limit of deltaic onlap. The location of the aggradation-incision boundary is controlled by upstream controls (discharge, sediment supply) as well as sea level (e.g. Blum \& Törnqvist, 2000; Cohen, 2005; Gouw \& Erkens, 2007). Aggradation in the western part of the Rhine-Meuse delta started about $8000{ }^{14} \mathrm{C}$ yr BP as a result of proceeding relative sea-level rise. No avulsions took place prior to $8000{ }^{14} \mathrm{C}$ yr BP: the first ones were initiated around $7500{ }^{14} \mathrm{C}$ yr BP (Stouthamer \& Berendsen, 2000). Aslan \& Blum (1999) described changing avulsion style in the Texas Gulf Coast Plain (USA) in response to varying aggradation rates. In the early stages of valley filling and low aggradation rates, avulsion occurs by reoccupation of Late-Pleistocene palaeo-channels (Fig. 6a). Avulsion by diversion into the floodplain occurs at high aggradation rates in a later stage of valley filling (Fig. 6b). Finally, avulsion by channel reoccupation takes place in late stages of valley filling at low aggradation rates (Fig. 6c).

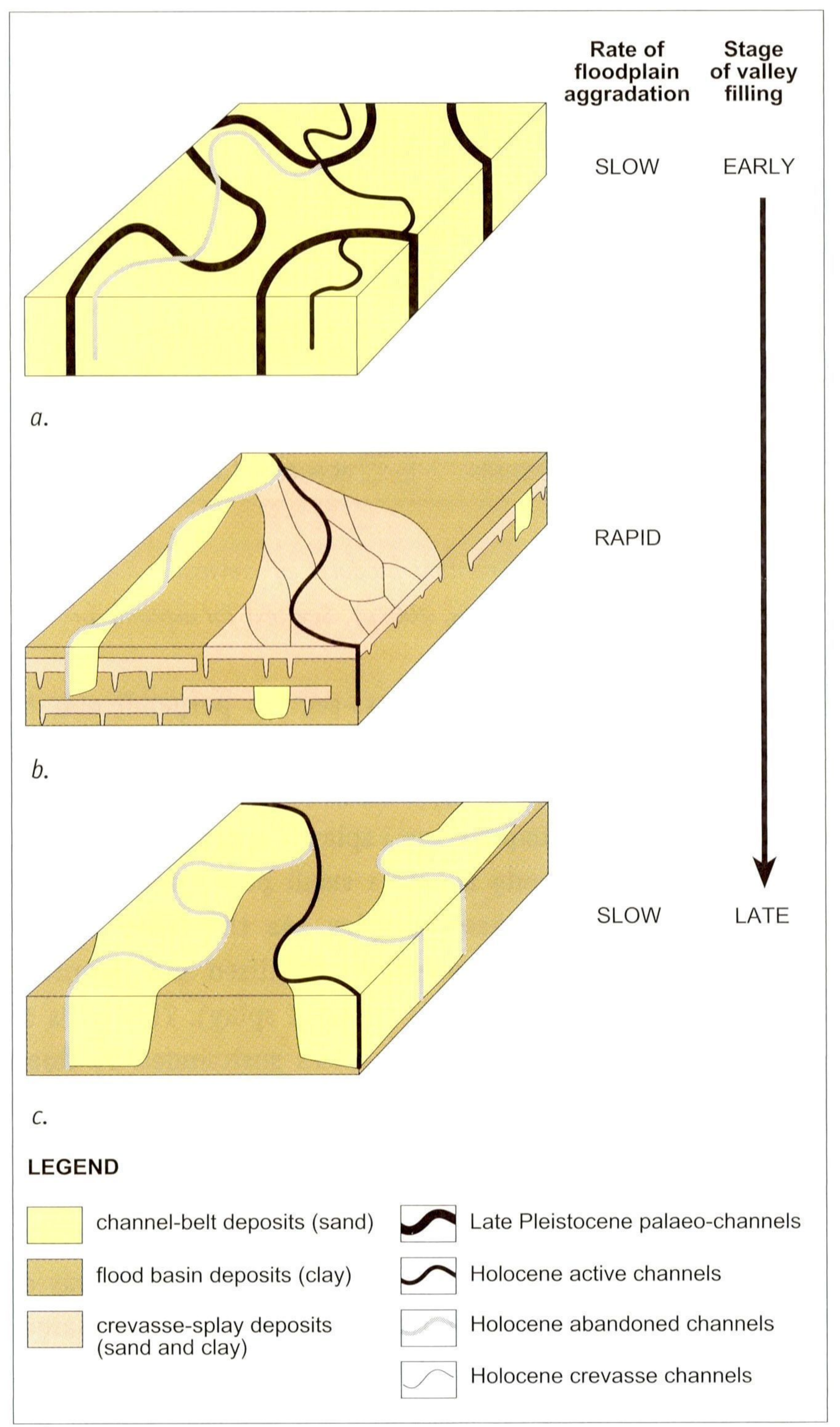

Fig. 6. Block diagrams showing different avulsion styles in the Texas Gulf Coast Plain (USA) as related to aggradation rate and valley fill stage (Aslan \& Blum, 1999). a. Avulsion by channel reoccupation of Late Pleistocene paleo-channels at slow aggradation rates at the beginning of valley filling; $b$. Avulsion by diversion into flood basins during stages of rapid valley fill; c. Avulsion by channel reoccupation of abandoned Holocene channels during periods of slow aggradation rates and late stages of valley filling. 


\section{Climate}

It is extremely difficult to distinguish climatic factors from others affecting alluvial architecture (Berendsen \& Stouthamer, 2001). Climate certainly plays a role in the development of fluvial systems (Vandenberghe, 1995), but fluvial response to (global) climatic changes varies spatially due to threshold differences between river systems (Blum \& Törnqvist, 2000). Changes from braided to single-thread channels at the Late Glacial-Early Holocene transition have been observed in many parts of the world (reviewed in Blum \& Törnqvist, 2000), including the Rhine-Meuse delta (Pons, 1957; Berendsen et al., 1995) and the Lower Mississippi Valley (Fisk, 1944; Kolb et al., 1968; Autin et al., 1991; Saucier, 1994). Bridge (2003, p. 359) stated that such changes in channel planform result from changes in discharge and sediment supply, and these in turn may be related to climatic changes.

Global climate change has a pronounced effect on sea level. After the LGM, sea level rose about 120 m (e.g. Chappell et al., 1996). This changed the position of the aggradation-incision boundary of the LGM and Holocene deposits in many river systems at continental margins. This feature has been reported for, amongst others, the Rhine-Meuse delta (Van Dijk et al., 1991; Stouthamer \& Berendsen, 2000, 2001; Cohen et al., 2002; Cohen, 2005) and the Colorado River, USA (Blum \& Price, 1998)
(Fig. 7). Upstream from the aggradation-incision boundary, rivers degrade and the youngest deposits occur at the lowest level in the terraced river valley (Fig. 7a). 0n the contrary, net aggradation occurs downstream from the aggradation-incision boundary and the sea-level low-stand sediments are covered by younger high-stand deposits (Fig. 7b). Climatic changes thus affect large-scale aggradation and degradation patterns in river systems (see reviews in, e.g., Blum \& Törnqvist, 2000; Bridge, 2003).

\section{Tectonics}

Differential subsidence within a deltaic system determines the location of channel belts and the distribution of fluvial sediments (e.g. Alexander \& Leeder, 1987; Leeder, 1993; Stouthamer \& Berendsen, 2000). It causes changes in local accommodation space, thus aggradation rates, and it affects trends in sedimentary patterns (Cohen et al., 2005). Gradually changing floodplain topography due to ongoing small crustal movements causes local changes in river and floodplain gradients, which affects the chances for avulsion (Alexander \& Leeder, 1987; Mackey \& Bridge, 1995). Changing river gradient may cause a change in channel behaviour resulting in incision or (increased) aggradation (e.g. Leeder, 1993; Holbrook \& Schumm, 1999). Avulsions can also occur as a direct consequence of tectonic

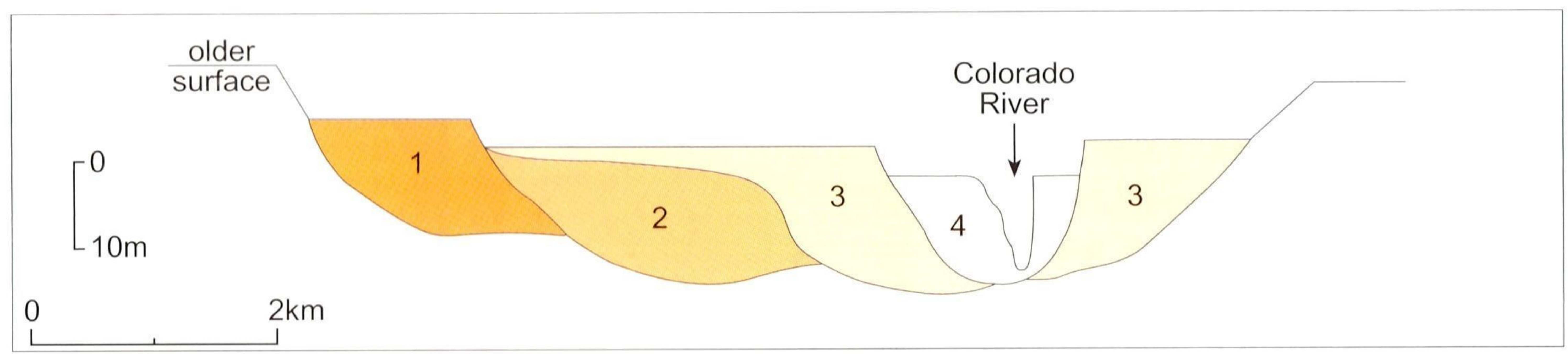

a.

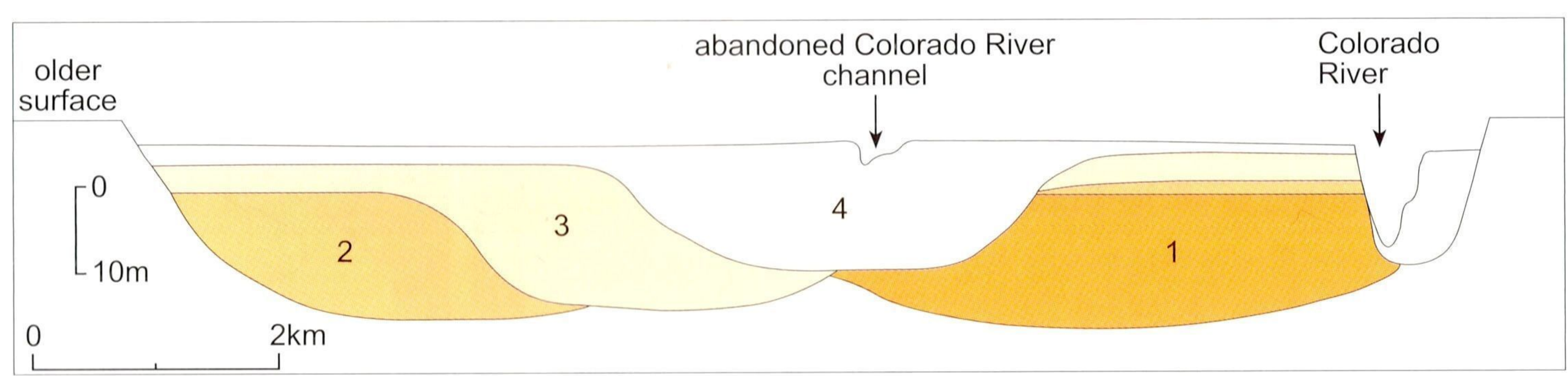

b.

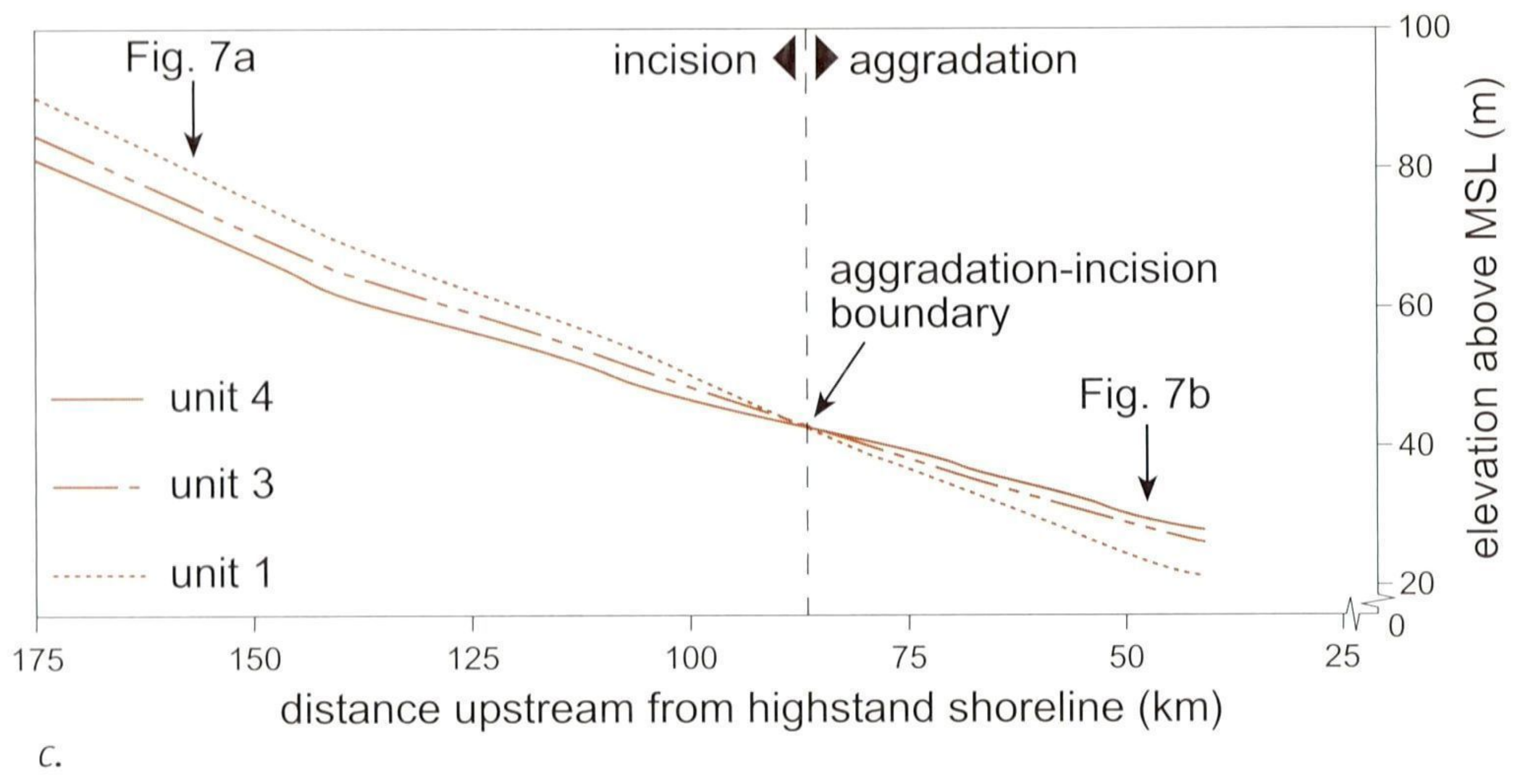

Fig. 7. Schematic cross-sections of the Late Pleistocene and Holocene deposits (unit 1 is older than unit 4) of the Colorado River, Texas Coastal Plain, USA (Blum \& Price, 1998, modified by Blum \& Törnqvist, 2000). a. Terraced landscape upstream from the aggradation-incision boundary. The youngest deposits (unit 4) are at the lowest level. b. Valley-fill downstream from the aggradation-incision boundary. The younger deposits are at a higher level than the older ones. c. Longitudinal profiles for the units 1, 3, and 4. The location of the aggradation-incision boundary and the cross sections is indicated. 
activity. Earthquakes may lead to collapsing natural levees, which causes crevassing and avulsion (Fisk, 1944; Alexander \& Leeder, 1987). Moreover, active faulting can influence avulsion locations. For example, Stouthamer \& Berendsen (2000) related four avulsion nodes (defined as locations where more than two avulsions have taken place within a distance of $5 \mathrm{~km}$ ) in the Rhine-Meuse delta to tectonic movements along faults.

\section{Aggradation}

Net channel-belt and floodplain aggradation occurs in cases of a high sediment supply relative to river discharge and/or when relative base-level rise (absolute sea-level rise, basin subsidence or both) creates accommodation space. Aggradation varies in space and time. At the scale of sedimentary basins, the pattern of sedimentation in the basin reflects the orientation of basin subsidence and/or base-level changes. In fore-tilted basins or in case of rising base level, aggradation rates increase down-basin, while in back-tilted basins aggradation rates decrease down-basin (Heller \& Paola, 1996). For instance, average aggradation rates in the Rhine-Meuse delta were at its highest during rapid sea-level rise in the first part of the Holocene (Van Dijk et al., 1991; Törnqvist, 1993b; Cohen, 2005) and increased downstream, towards the direction of maximum subsidence (Törnqvist et al., 1993, p. 213; Cohen, 2005). Aggradation rates may vary locally due to differential subsidence resulting from neotectonic activity. For instance, aggradation rates in the central Rhine-Meuse delta were locally higher than in the lower delta (Cohen, 2003). Spatiotemporal variations in aggradation rates are thought to affect avulsion (see below) and concurrent sedimentation patterns, which influences alluvial architecture.

Aggradation rates also vary with distance from the river channel: the highest rates occur close to the channel (Pizzuto, 1987; Bridge \& Mackey, 1993a; Mackey \& Bridge, 1995; Törnqvist \& Bridge, 2002). Some workers suggested that the differential sedimentation rate between the channel belt and the adjacent flood basin is the driving force for avulsion, as will be discussed below.

\section{Avulsion}

Avulsion has a profound influence on alluvial architecture, because it controls the areal distribution of channel belts on the floodplain and thereby the location of the depositional environments (e.g. Bridge \& Leeder, 1979; Stouthamer, 2001a). The number of active channels within a fluvio-deltaic system partly depends on the relationship between the avulsion frequency, avulsion duration, and inter-avulsion period (avulsion parameters cf. Stouthamer \& Berendsen, 2001). Avulsion frequency is defined as the number of avulsions per time interval in a given area, avulsion duration as the time period between initiation of a new channel and

complete abandonment of the previous one, and inter-avulsion period as the time period between successive avulsions. For example, if avulsion frequency increases, and the avulsion duration and inter-avulsion period remain constant, the number of active channels on the floodplain increases. Consequently, CDP increases and connectedness may also increase. Stouthamer \& Berendsen (2007) showed that avulsion frequency and inter-avulsion period varied in the Rhine-Meuse delta during the Holocene, albeit the trends were different. The avulsion frequency decreased until $\sim 3200{ }^{14} \mathrm{C}$ yr BP and increased between 3200 and $1800{ }^{14} \mathrm{C}$ yr BP. The inter-avulsion period increased until $2800{ }^{14} \mathrm{C}$ yr BP and decreased afterwards. Data from other river systems suggest that other relationships between the avulsion parameters are possible (Stouthamer \& Berendsen, 2001), each of which influences alluvial architecture in a different way.

Various classifications have been proposed to distinguish avulsion behaviour. Leeder (1978) described nodal and random avulsion (Fig. 8). Nodal avulsions take place at or close to a fixed point on the floodplain, which can be located anywhere on the floodplain (Fig. 8a). Random avulsion, however, occurs anywhere along the active channel (Fig. 8b). Heller \& Paola (1996) characterised avulsions based on downstream distance over which the new channel remains outside its former course.

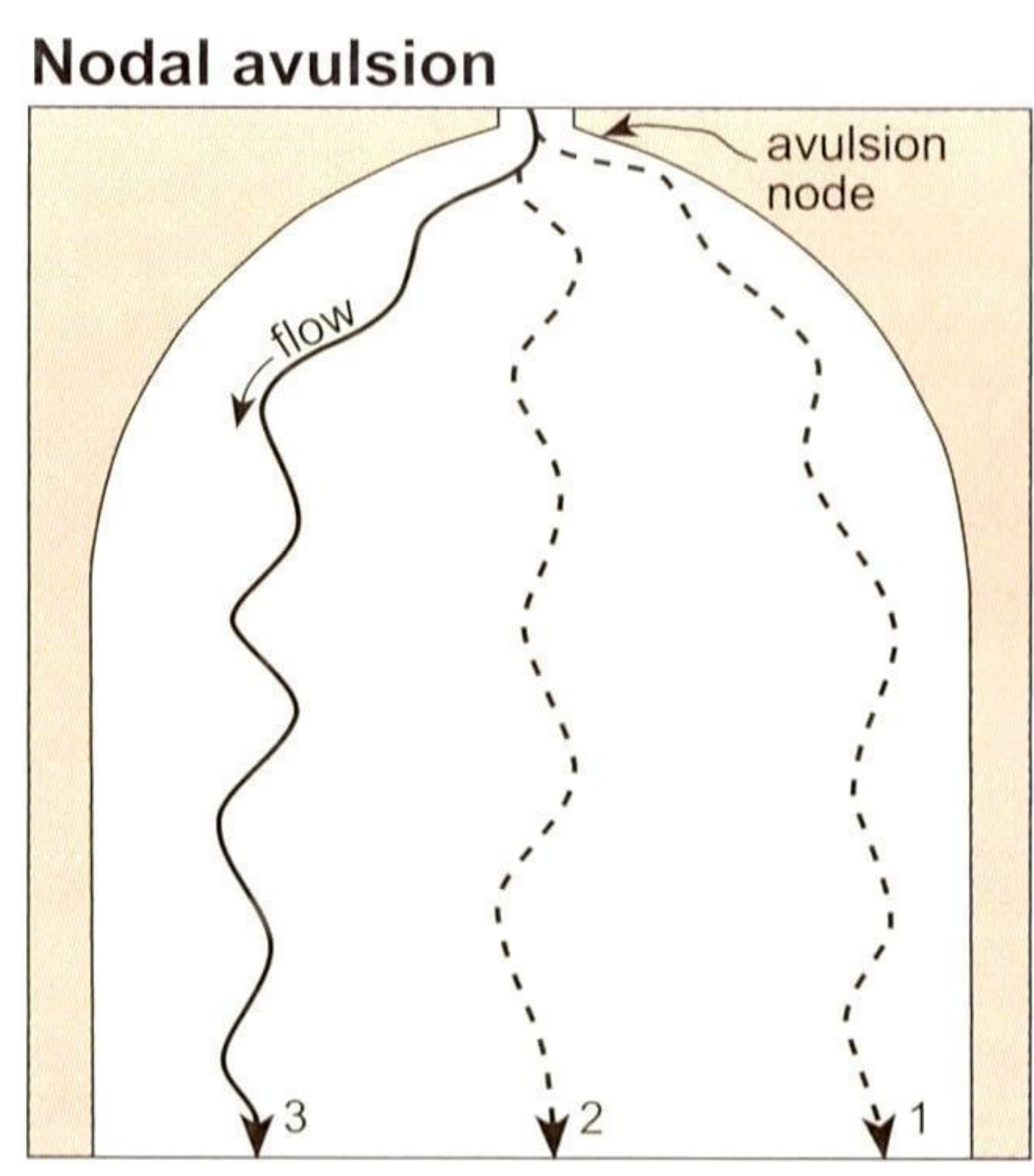

a.

Local avulsion

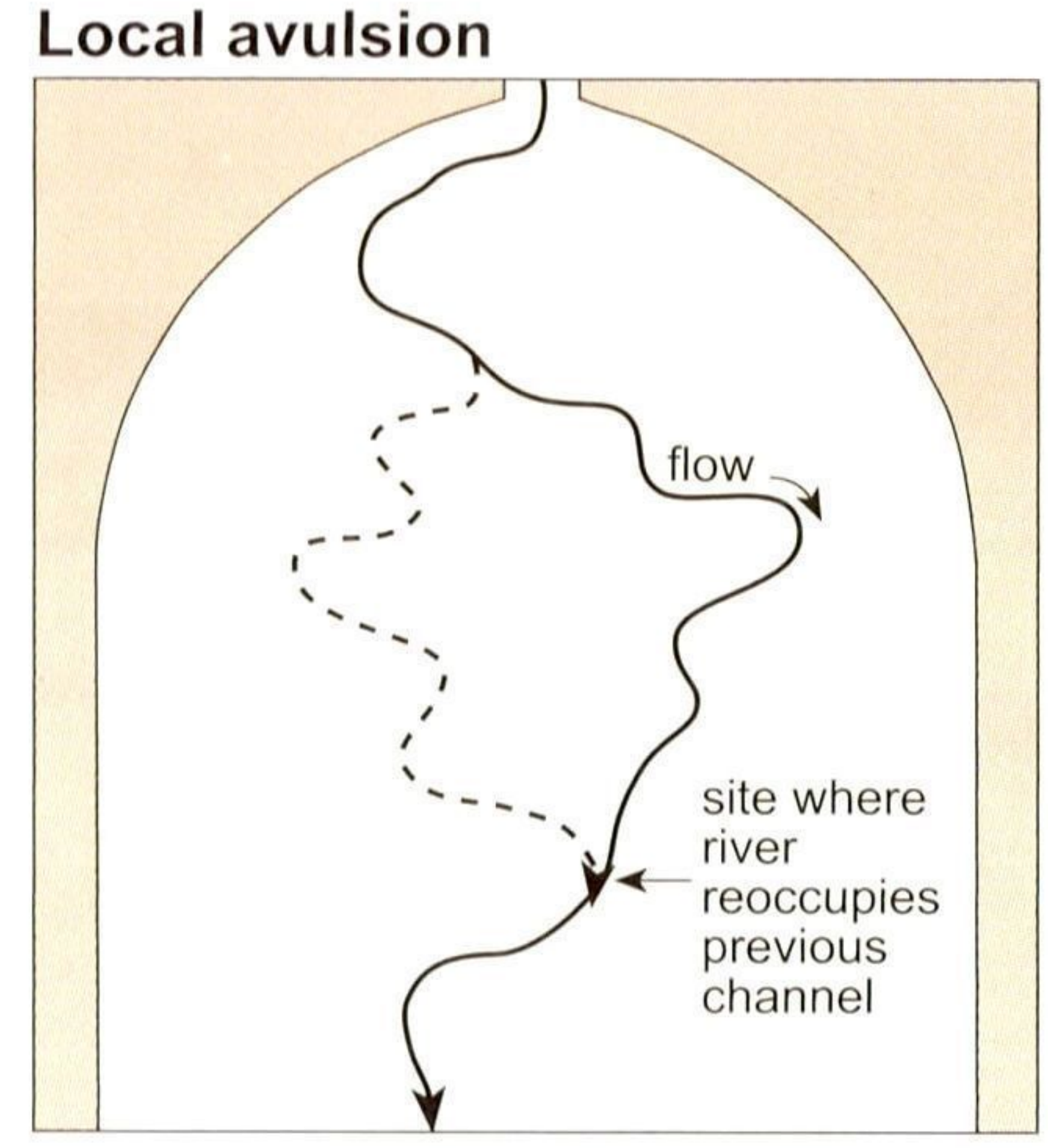

c.

active channel

- . - . - a abandoned channel

Fig. 8. Avulsion types. Leeder (1978) recognised nodal avulsion (a) and random avulsion (b), Heller \& Paola (1996) distinguished local avulsion (c) and regional avulsion (d). 
Local avulsion occurs if the new channel reoccupies the former one downstream from the avulsion point (Fig. 8c). Regional avulsion occurs when an entire new channel is formed which does not reoccupy the old channel (Fig. 8d).

Avulsion style describes the way a channel avulses. Slingerland \& Smith (2004) summarised the various avulsion styles that have been recognised as follows:

1. Avulsion by annexation, in which an active channel is captured or an abandoned channel is reoccupied (e.g. Aslan \& Blum, 1999; Morozova \& Smith, 1999; Mohrig et al., 2000; Aslan et al., 2005; Stouthamer, 2005);

2. Avulsion by incision, which involves scouring of new channels into the flood plain (incisional avulsion cf. Mohrig et al., 2000);

3. Avulsion by progradation, in which discharge is diverted into the flood basin accompanied by large-scale deposition (e.g. avulsion by diversion into the flood basin cf. Aslan \& Blum, 1999; aggradational avulsion cf. Mohrig et al., 2000).

\section{Avulsion mechanics}

The avulsion process can be characterised as having two basic requirements: a 'setup', where the river aggrades and becomes increasingly susceptible for avulsion, and a 'trigger', which is an event (for example, a large flood) causing the actual abandonment of the channel in favour of a new course (Jones \& Schumm, 1999; Mohrig et al., 2000; Slingerland \& Smith, 2004). Avulsion setup is commonly considered to be a result of differential sedimentation rates between the channel and the adjacent flood basin. The sedimentation rate of a river is greatest in and near the channel and decreases with distance from the channel-belt edge (Fisk, 1944; Pizzuto, 1987; Bridge \& Mackey, 1993a; Mackey \& Bridge, 1995; Törnqvist \& Bridge, 2002). Consequently, the channel belt becomes elevated above the adjacent floodplain.

Two different views regarding the character of avulsion setup exist. The first view is the 'gradient-advantage concept', in which the ratio between cross-valley slope (i.e. levee slope cf. Mohrig et al., 2000; Fig. 9) and down-valley slope, referred to as slope ratio, should reach a critical value for avulsion to occur (Mackey \& Bridge, 1995; Slingerland \& Smith, 1998, 2004; Törnqvist \& Bridge, 2002). Slope ratios of $>8$ (Slingerland \& Smith, 1998) or 3 - 5 (Törnqvist \& Bridge, 2002) have been proposed as possible important threshold values. The second view is the 'superelevation concept', in which avulsion is driven by the difference in elevation between the levee crest (i.e. water surface at bankfull discharge) and the adjacent floodplain surface (Fig. 9), referred to as superelevation (Bryant et al., 1995; Heller \& Paola, 1996; Mohrig et al., 2000). To be able to compare different rivers, the ratio between superelevation and bankfull channel depth (normalised superelevation) is commonly used (Mohrig et al., 2000; Swenson, 2005). Mohrig et al. (2000) reported that normalised superelevation values of $0.6-1.1$ are needed for channels to avulse. The two avulsion-setup concepts obviously may be correlated if crossvalley slope steepens as superelevation height increases (Slingerland \& Smith, 1998 in Mohrig et al., 2000).

Despite the progress made in understanding the avulsion process, the primary control on avulsion setup (gradient advantage vs. superelevation) is still subject of debate. Field studies of Aslan et al. (2005) and Mohrig et al. (2000) suggest that gradient advantage probably is less important for avulsion setup than superelevation (cf. Bryant et al., 1995; Heller \& Paola, 1996; Mohrig et al., 2000). Aslan et al. (2005) stated that gradient advantage is not the primary control on Holocene Mississippi River avulsion. They found slope ratios generally greater than 30 , which is significantly larger than the critical values reported by Slingerland \& Smith (1998) and Törnqvist \& Bridge (2002), and yet Mississippi River avulsions were rare. In their elaborate field study on modern and ancient alluvial successions, Mohrig et al. (2000) found that normalised superelevation values for modern channels that have avulsed are very similar, whereas slope ratios show large differences. Törnqvist \& Bridge (2002), however, indicated that both slope ratio and normalised superelevation may show a large scatter. They concluded that avulsion dynamics probably depend on the gradient of the fluvial setting (e.g. low-gradient deltaic systems vs. high-gradient alluvial fans), a view supported by Ashworth et al. (2004), and that avulsion setup cannot be characterised by just one measure (critical slope ratio or superelevation).

Alternative views on avulsion dynamics include the channel-capacity avulsion model of Makaske (2001). A reduction of stream power may result in increased withinchannel sedimentation, limiting water flow and sediment transport capacity of the channel, which leads to avulsion

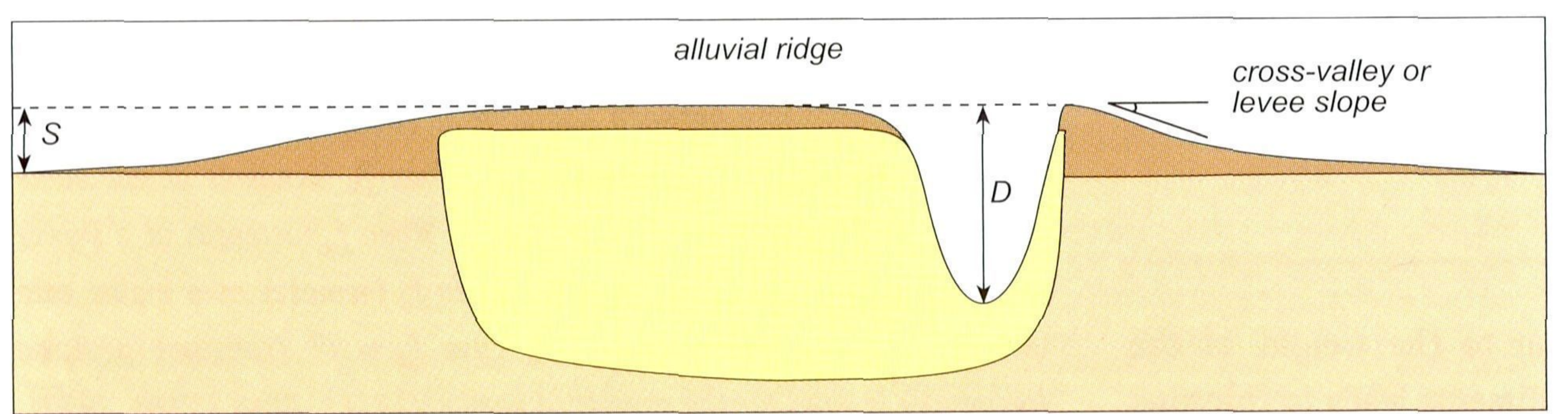

LEGEND

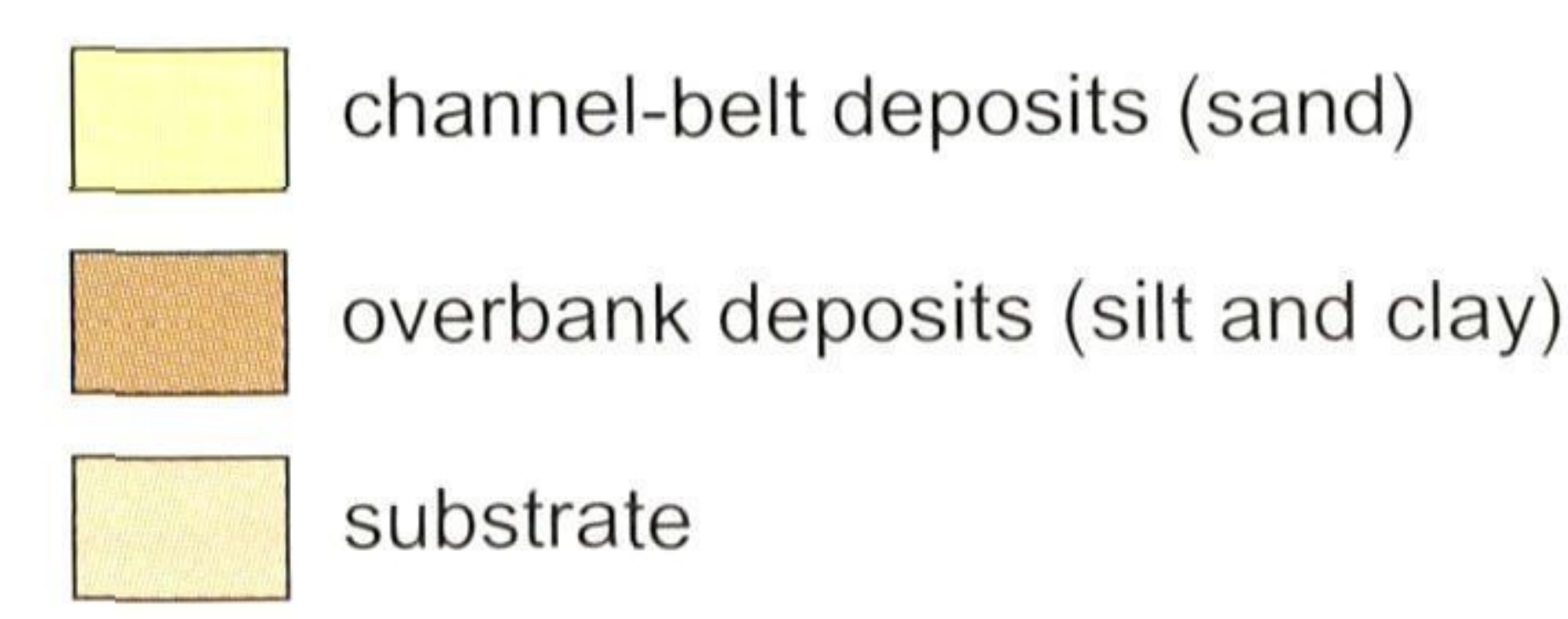

Fig. 9. Cross-sectional diagram showing cross-valley slope (i.e. levee slope), superelevation (S), and bankfull channel depth (D) of an alluvial ridge. Normalised superelevation is S/D. After Bryant et al. (1995) and Mohrig et al. (2000). 
(Makaske, 1998, 2001). Furthermore, it should be kept in mind that other factors also control avulsion, such as floodplain topography (e.g. reoccupation of abandoned channels; Smith et al., 1998; Aslan \& Blum, 1999; Mohrig et al., 2000) and substrate composition (e.g. Aslan et al., 2005). In addition, Swenson (2005) noted that nearshore processes (i.e. wave energy) may suppress river avulsion.

Although avulsions can also occur without large-scale aggradation (see references in Slingerland \& Smith, 2004), the chances for avulsion are thought to increase with increasing aggradation rates (reviewed in Slingerland \& Smith, 2004). In view of this, many studies focused on the relationship between avulsion frequency and aggradation rate and/or sediment supply (e.g. Bryant et al., 1995; Heller \& Paola, 1996; Törnqvist \& Bridge, 2002; Ashworth et al., 2004, 2007). In the mid-1990s, Bryant et al. (1995) and Heller \& Paola (1996) published their experimental studies on controls on channel interconnectedness $(C R)$. Their fundamental premise was that avulsion frequency heavily depends on aggradation rate ('sediment accumulation rate' cf. Heller \& Paola, 1996). The relationship between avulsion frequency $\left(f_{a}\right)$ and aggradation rate $(r)$ is given as $f_{a} \infty r^{b}$, where $b \geqslant 0$ (Fig. 10), i.e. avulsion frequency always increases with aggradation rate (Bryant et al., 1995; Heller \& Paola, 1996). Bryant et al. (1995) and Heller \& Paola (1996) state that a high $r$ does not always cause a low $C R$, as is the case in the early alluvialarchitecture models. $C R$ may well increase with increasing $r$, as long as $f_{a}$ increases faster than $r\left(b>1\right.$; Fig. 10c). When $f_{a}$ increases linearly with $r(b=1), C R$ does not change despite increasing $r$ (Fig. 10a). When $f_{a}$ increases at a slower rate than $r(\mathrm{~b}<1), C R$ decreases (Fig. 10b). Bryant et al. (1995) found that $f_{a}$ increases faster than $r(\mathrm{~b}>1)$ on a simulated alluvial fan. Ashworth et al. (2004, 2007), in modelling experiments of a braided river, found the opposite $\left(f_{a}\right.$ increases at a slower rate than $r$ and $b<1$ ).

Because of its significant effect on alluvial architecture, Heller \& Paola (1996) concluded that the relationship between avulsion frequency and aggradation rate should be incorporated in future alluvial-architecture models. Data from modern river deltas is ambiguous, however. Törnqvist (1994) suggested that avulsion frequency is positively correlated with aggradation rate in the Holocene Rhine-Meuse delta, whereas Stouthamer \& Berendsen (2001) found high avulsion frequencies during low aggradation rates. Stouthamer (2005) noted that the ratio between local (natural levee) and regional (flood basin) aggradation rate probably is important for avulsion frequency.

\section{Compaction}

When buried, sediments compact due to the weight of the overlying sediments. Compaction of sediments leads to thinning and deformation of sediment layers and thereby affects alluvial architecture. Compaction of channel belts is minimal (at least for burial depths less than 500 m; Bridge \& Mackey, 1993a), whereas clay and especially peat compact strongly, even at shallow burial depths. In a modelling study on compaction in deltaic plains, Meckel et al. (2007) suggested that compaction rates are generally less than a few mm per year but nevertheless can account for much of the accommodation space created.

Differential compaction constantly alters floodplain topography, which may affect the position of new channel belts and sedimentation patterns on the floodplain (Bridge \& Leeder, 1979). Alluvial ridges, partially formed because of differential
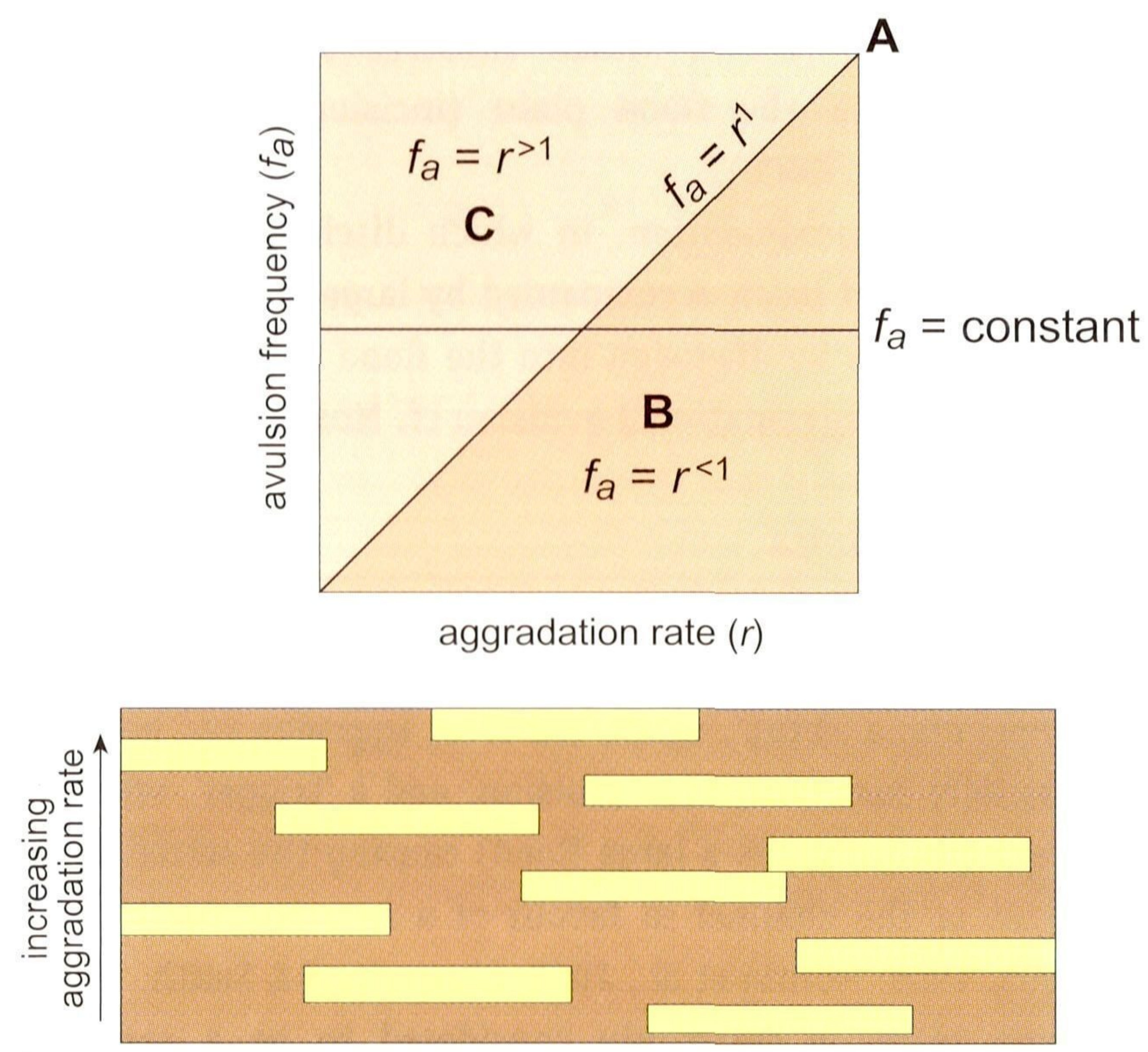

a.

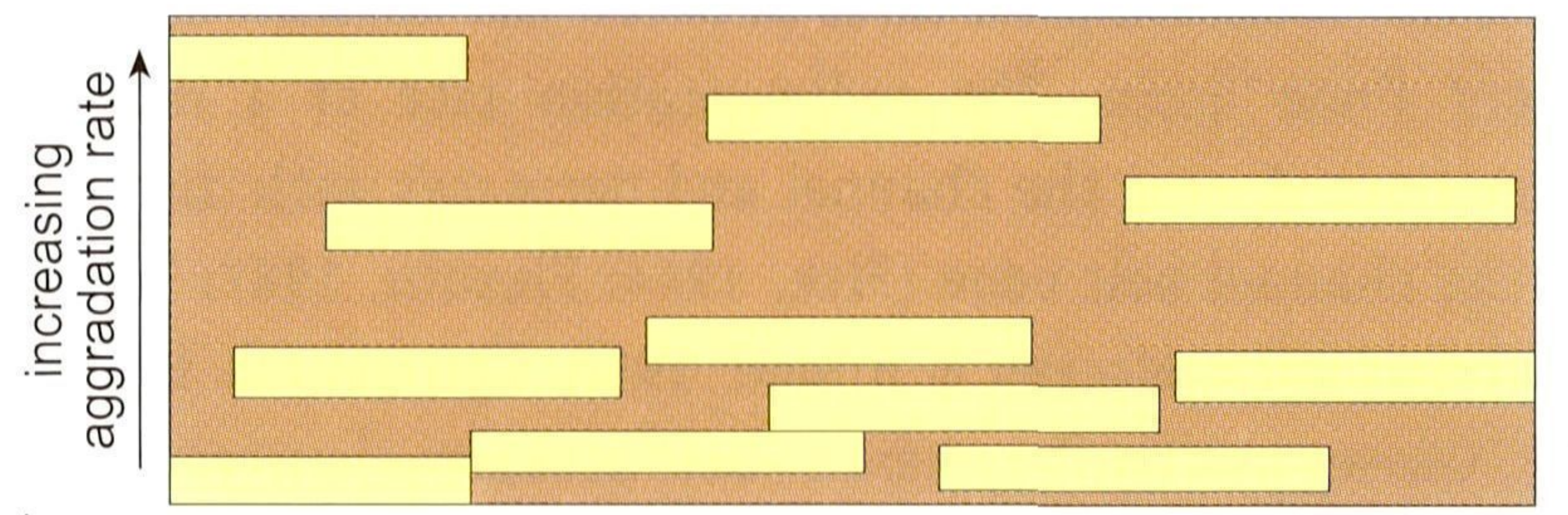

b.

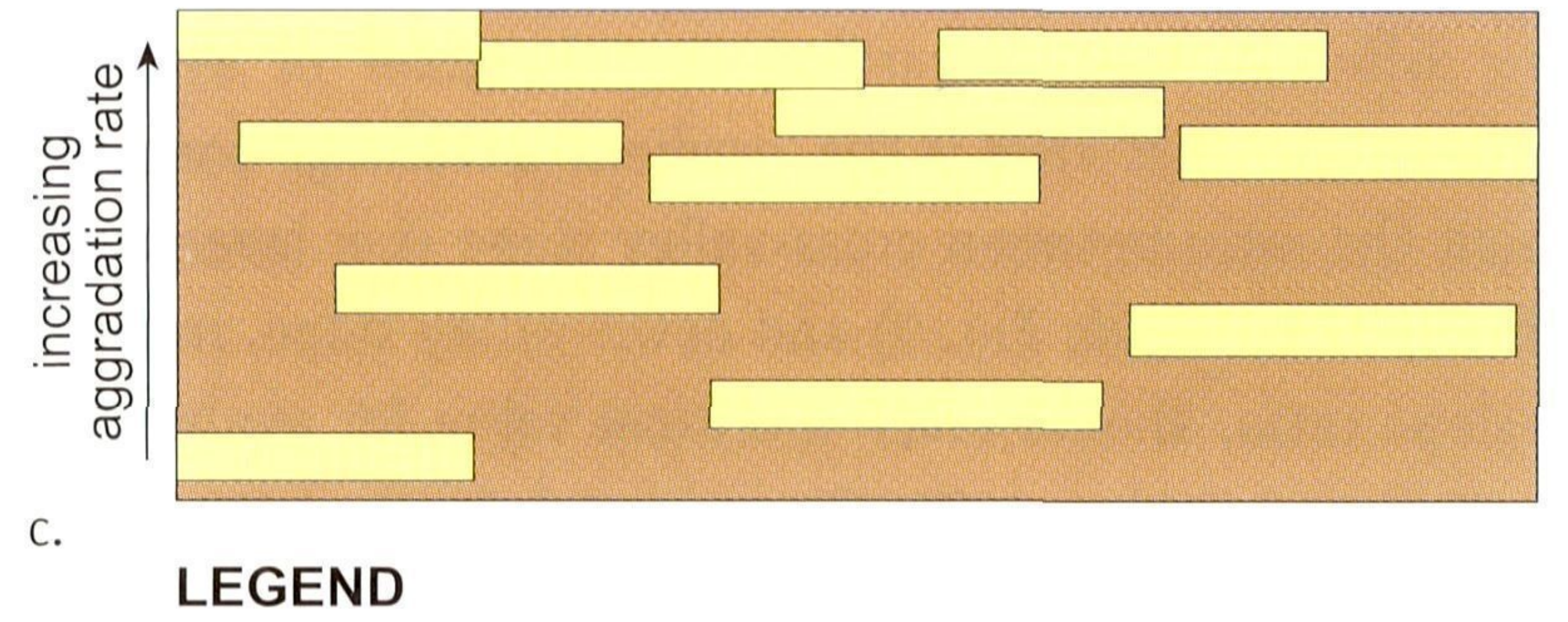

channel-belt deposits

overbank deposits

Fig. 10. Relationship between aggradation rate ( $r)$, avulsion frequency $\left(f_{a}\right)$, and the resultant architecture. $a$. When $f_{a}$ increases at the same rate as $r$, architecture does not change. $b$. When $f_{a}$ increases at a slower rate than $r, C D P$ and $C R$ decrease. c. When $f_{a}$ increases at a higher rate than $r, C D P$ and $C R$ increase. The case $f_{a}=r^{0}$ (constant avulsion frequency) is valid for the models of Leeder (1978), Allen (1978, 1979), Bridge \& Leeder (1979), and Bridge \& Mackey (1993a) (Heller \& Paola, 1996). 
compaction, can act as boundaries for floodplain deposition. Sedimentation during floods is constrained to a certain area bordered by high-standing alluvial ridges. In the Cumberland Marshes (Canada), for example, Pérez-Arlucea \& Smith (1999) found two vast areas with crevasse-splay deposits that are separated by an alluvial ridge.

\section{Process-based alluvial-architecture models}

Alluvial-architecture models simulate the spatial distribution and proportion of fluvial sand(stone) bodies in alluvial sequences. Mackey \& Bridge (1995, p. 14) define a sand body as "any number of channel belts that are connected to each other but not connected to any other sandstone body". A sand body, as defined here, may therefore be composed of several channel belts separated by fine-grained overbank deposits (Fig. 11). Nevertheless, they are regarded as a single sand body in alluvial-architecture models. Sand-body thickness $(S B T)$ is the maximum vertical distance between the upper and lower boundary of the sand body, whereas sand-body width $(S B W)$ is defined as the maximum horizontal distance between the edges of the sand body (Fig. 11) (Mackey \& Bridge, 1995).

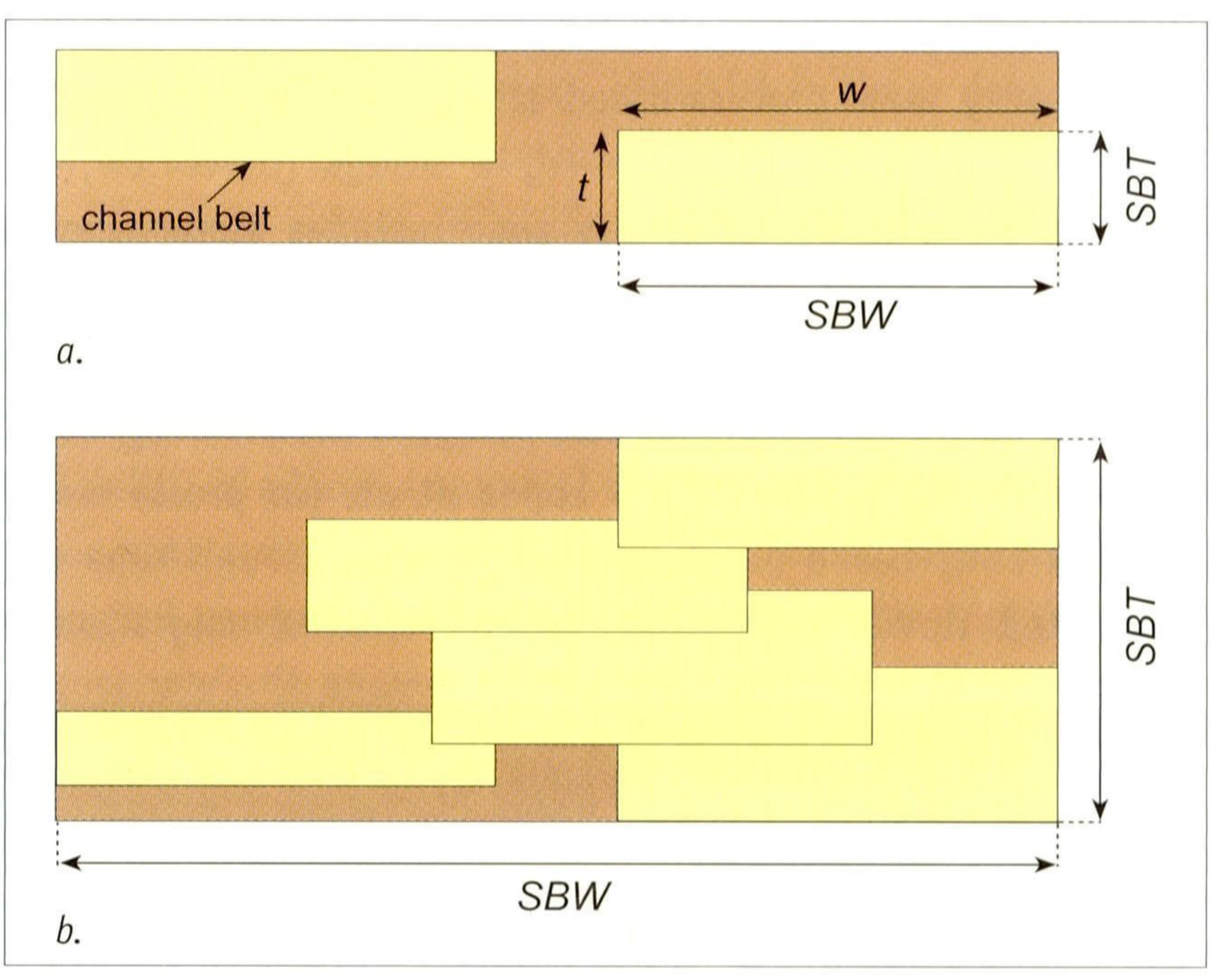

\section{LEGEND}

$$
\begin{aligned}
& \text { channel-belt deposits (sand) w channel-belt width } \\
& \text { overbank deposits (clay) } \quad t \quad \text { channel-belt thickness }
\end{aligned}
$$

Fig. 11. Diagrams showing sand-body dimensions as defined by Mackey \& Bridge (1995). Individual channel belts are shown as boxes. a. Unconnected channel belts. Sand-body width (SBW) and sand-body thickness (SBT) equal channel-belt width (w) and channel-belt thickness $(t)$, respectively. The sand bodies are entirely composed of channel-belt sands. $b$. Connected channel belts: $S B W>w$ and $S B T>>t$. The sand body incorporates fine-grained overbank deposits (after Mackey \& Bridge, 1995).
In general, two modelling approaches can be distinguished (e.g. Karssenberg et al., 2001; Bridge, 2003): structure-imitating and process-based modelling of alluvial architecture. Structureimitating models do not include fluvial processes, but simulate the arrangement of the architectural elements (notably sand bodies) within the alluvial sequence using stochastic methods. Numerical process-based models simulate the fluvial stratigraphy as a result of fundamental sedimentary processes, which is why it is commonly believed that process-based models produce more realistic simulations of fluvial successions (Karssenberg et al., 2001). Therefore, this section highlights process-based alluvial-architecture models by giving an overview of the development of these models.

\section{Two-dimensional models of alluvial architecture}

The models of Leeder (1978), Allen (1978, 1979), and Bridge \& Leeder (1979)

In the late 1970s, Leeder (1978), Allen (1978, 1979), and Bridge \& Leeder (1979) presented their models to explore the controls on superposition of channel belts. They simulated the two-dimensional alluvial architecture of a floodplain containing one active channel. The simulated alluvial architecture depends on floodplain geometry, channel planform and geometry, vertical floodplain accretion, and avulsion period. Furthermore, Allen (1978, 1979) and Bridge \& Leeder (1979) incorporated differential compaction and its influence on avulsion, though in a very simplified form. Bridge \& Leeder (1979) introduced tectonic movements and variation of aggradation rate with distance from channel belts. The most striking result of the models was the concept that, while avulsion frequency is constant, $C D P$ and $C R$ decrease with increasing sedimentation rate and vice versa.

\section{The Bridge \& Mackey-model (1993)}

Bridge \& Mackey (1993a) published a modification of the Bridge \& Leeder (1979) alluvial-architecture model. In the improved model, they added burial depth (affecting compaction) and tectonic tilting of the floodplain normal to palaeo-flow (Bridge \& Mackey, 1993a). In accordance to the models aforementioned, the 1993 Bridge \& Mackey-model predicts decreasing CDP and $C R$ values with increasing sedimentation rates at constant avulsion frequency. In addition, the model shows a drastic increase of $C D P$ after compaction of sequences with an initial (i.e. before burial occurs) high proportion of overbank deposits.

Parallel to the improved model, Bridge \& Mackey (1993b) published a theoretical study on fluvial sand-body dimensions. Their results suggest a strong correlation between $C D P$ and the dimensions of the sand bodies in cross-sectional view (Bridge \& Mackey, 1993b). When CDP values are low, the individual channel belts are virtually unconnected ( $C R$ approaches 0$)$. In 
that case, sand-body width $(S B W)$ equals channel-belt width (w) (Figs 11a and 12) and sand-body thickness (SBT) is identical to channel-belt thickness $(t)$. For $C D P$ values $>0.75$, all channel belts are connected and $S B W$ equals the width of the floodplain $(W)$ (Fig. 12).

The 1993 Bridge \& Mackey-model contains some great improvements compared to the models of Leeder (1978), Allen (1978, 1979), and Bridge \& Leeder (1979) with respect to description of depositional processes. The improved model explicitly considers compaction and effects of differential floodplain aggradation (Bridge \& Mackey, 1993a). The process of avulsion in relation to varying aggradation rates, local floodplain slope, and tectonism is not incorporated, however.

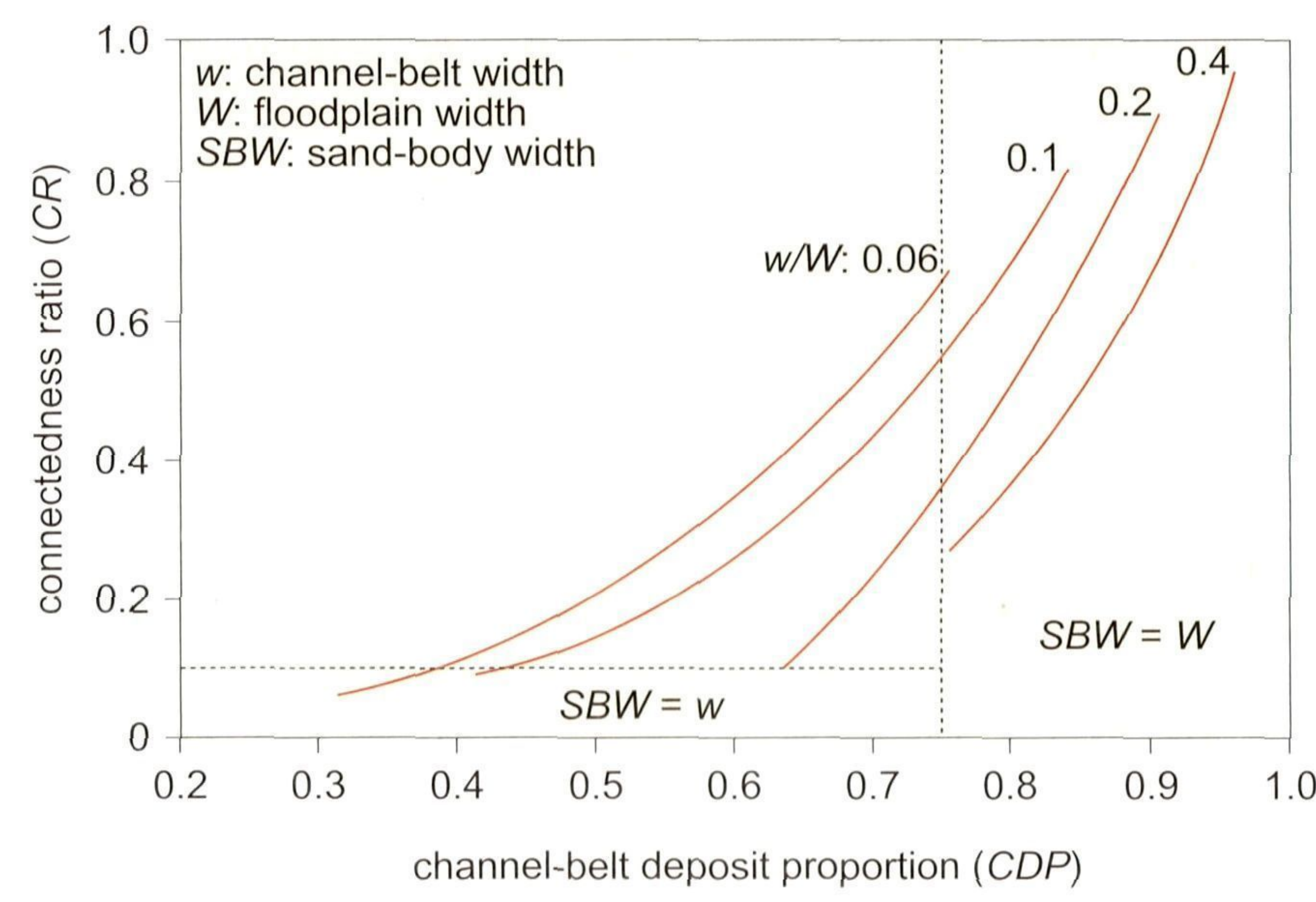

Fig. 12. Dependence of CR on CDP for varying ratios of channel-belt width (w) to floodplain width (W). All channel belts are connected (SBW $=W$ ) when CDP exceeds 0.75 (after Bridge \& Mackey, 1993b).

\section{Three-dimensional alluvial-architecture model of Mackey \& Bridge (1995)}

Mackey \& Bridge (1995) published the first three-dimensional process-based model of fluvial stratigraphy. In their model, alluvial architecture is simulated as a function of the ratio of channel-belt width to floodplain width, bankfull channel depth, channel-belt and overbank sedimentation rates, avulsion location and period, compaction, and tectonism (tilting and faulting). The coupling of avulsion frequency to aggradation rate in the 1995 Mackey \& Bridge-model is considered to be a significant improvement compared to the earlier models (Mackey \& Bridge, 1995). Downstream increasing aggradation rates (common in settings with a rising base level) may lead to high avulsion frequencies in the model, which results in high $C D P$ and $C R$ values in the downstream reaches of the modelled fluvial succession. This is opposite to the aforementioned models that predicted low $C D P$ and $C R$ values under high aggradation rates. Mackey \& Bridge (1995) feel that the early models are oversimplified because these consider aggradation rate as the main factor controlling alluvial architecture.

The model predicts that the alluvial architecture varies with distance from avulsion locations. For example, sand-body width/thickness ratios (SBW/SBT) are low upstream from avulsion locations. Immediately downstream from the avulsion, SBW/SBT increases significantly. Mackey \& Bridge (1995) stated that the relationship between $C D P$ and $C R$, as suggested in the two-dimensional models (Fig. 12; Bridge \& Mackey, 1993b), is only valid in parts of the floodplain located a considerable distance downstream from avulsion locations. Faulting is incorporated in the three-dimensional model in addition to tilting in the previous models. In the model, tectonic tilting and faulting locally increase avulsion probabilities as channels more likely avulse to areas experiencing most subsidence. As a result, modelled $C D P$ and $C R$ are high in these areas.

Although the expansion to a three-dimensional model with coupling of avulsion frequency to aggradation rates is a significant step forward, Mackey \& Bridge (1995) suggested the following improvements to be made: 1) expansion with more than one channel on the floodplain; 2) development of a physically based model considering the influence of the external controls affecting alluvial architecture (base-level change, climate, and tectonism) on, amongst others, sediment supply and sedimentary processes; 3) incorporating the formation of crevasse splays, levees and lakes; and 4) testing the model with architectural data from modern river deltas.

Currently, new process-based alluvial-architecture models are being developed. Karssenberg \& Bridge (in review) are working on a model (Fig. 13) that includes simulation of sediment transport, channel bifurcation and avulsion, and aggradation and degradation of a floodplain containing multiple active channels (see also Bridge \& Karssenberg, 2005; Karssenberg \& Bridge, 2005). Lopez et al. (in press) model channel belts based on channel evolution through time and associated fluvial deposition. Lateral channel migration is

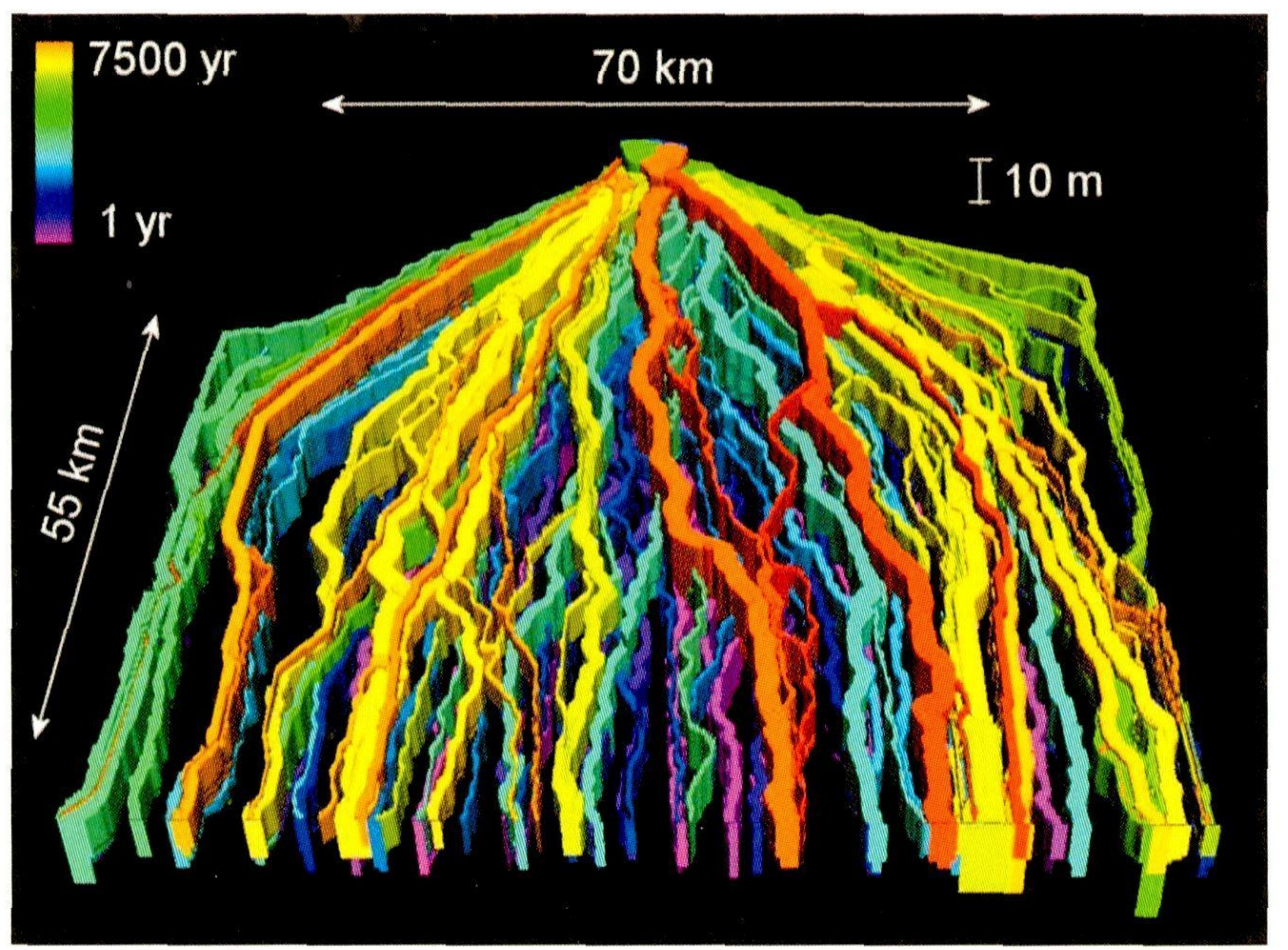

Fig. 13. Simulated channel-belt configuration on an alluvial fan as simulated by the new three-dimensional alluvial-architecture model of Karssenberg \& Bridge (Bridge \& Karssenberg, 2005; Karssenberg \& Bridge, 2005). Coloration of channel belts refers to time (in years). Downstream is to the bottom of the panel. 
included in their model that incorporates parameters such as avulsion frequency, available accommodation space, floodplain slope, channel dimensions (width and depth), frequency and intensity of floods, and erodibility.

\section{Challenges and future work}

The architecture of a fluvial succession is a result of the complex interaction between base-level movements, climate (affecting sediment supply and discharge), tectonics, aggradation, avulsion, and compaction. Therefore, a change in alluvial architecture cannot be attributed to one single control. To examine the relationships between the various controls, geologists commonly use models of fluvial stratigraphy (see references in Heller \& Paola, 1996). However, the power of the current models to predict alluvial architecture realistically is largely unknown due to a lack of quantitative field data to test the models (e.g. Mackey \& Bridge, 1995; Paola, 2000). As Paola (2000, p. 121) stated: "The main brake on the development of basin modelling is not computing power but lack of methods and data for testing the models we have already developed." More and more quantitative architectural data is becoming available, both from the ancient record (e.g. Bridge et al., 2000; Kombrink et al., 2007) and subrecent fluvial environments (Gouw, in press), albeit that these data essentially are based on cross sections and/or outcrops, thus twodimensional in nature. Since fluvial successions naturally are in three dimensions, the next step would be to work on threedimensional representations of fluvial successions. This is especially feasible for the Rhine-Meuse delta given the availability of a large amount of subsurface data that is needed to generate truthful three-dimensional fluvial stratigraphies. Geological computer software may be a suitable tool for this purpose when it enables geologists to digitise the 3D fluvial stratigraphy using field data from various kinds and sources such as geological maps, borings, and seismic data. Threedimensional representations of natural fluvial successions could be applied to study the volume, shape, and continuity of sediment bodies that constitute fluvial successions and to test 3D model output.

With regard to alluvial-architecture modelling, the main goal should be to simulate realistic channel-belt geometries. The common use of empirical formulas, that compute channelbelt width as a function of mean or maximum bankfull channel depth (Collinson, 1978; Williams, 1986; Fielding \& Crane, 1987; Bridge \& Mackey, 1993b), in alluvial-architecture models is problematic because: 1) determining bankfull channel depth (input parameter) from the (internal) geometry of ancient channel belts proved to be very difficult (Fielding \& Crane, 1987; Bridge \& Mackey, 1993b); 2) most empirical relationships are strongly biased towards meandering and braided channels (Bridge \& Mackey 1993b) and do not hold for straight channels that are common in fluvio-deltaic settings; 3) channel-belt width is always constant alongstream since mean or bankfull discharge is the only input parameter in the empirical formulas. However, the studies of Törnqvist et al. (1993), Makaske (1998), Makaske et al. (2007), and Gouw \& Berendsen (2007), showed that channel-belt width may vary considerably along the length of channel belts. Therefore, other methods than the usage of empirical relationships should be applied to realistically simulate channel belts in alluvial-architecture models. In structure-imitating models, a function describing the downstream narrowing of channel belts, which are encased in cohesive deposits, could be incorporated. Processbased models should include the driving factor 'stream power' and resisting factor 'bank erodibility', because these influence lateral migration rates of channels, thus channel-belt width. Stream power is a function of specific gravity, river gradient, and discharge, whereas bank erodibility varies with the lithological composition of the river banks. This approach is used in the newly-developed process-based model of Lopez et al. (in press), wherein the shape of a channel belt is modelled as a function of, amongst others, floodplain slope, channel width and depth, and bank erodibility. More physical data on the interaction between stream power, bank erodibility, and lateral channel migration is needed from modern rivers or flume experiments, however.

In the near future, the main challenges in alluvial-architecture research would be to keep gathering architectural data from various fluvial environments, to enhance our understanding of the physics of fluvial processes such as avulsion and lateral migration of channels, and to implement new data and process-knowledge into models. This is an impressive yet valuable task, because alluvial-architecture research is relevant not only for the scientific community (e.g. deltaevolution), but also for the commercial world (hydrocarbon exploration and production).

\section{Acknowledgements}

I thank NJG guest editors Hans Middelkoop, Esther Stouthamer and Wim Hoek for the invitation to publish this paper. Henk Berendsen, Kim Cohen, Gilles Erkens, Ward Koster, and Esther Stouthamer commented on earlier drafts of the manuscript. Torbjörn Törnqvist is thanked for his helpful review, which improved the paper significantly. 


\section{References}

Alexander, J. \& Leeder, M.R., 1987. Active tectonic control on alluvial architecture. In: Etheridge, F.G., Flores, R.M. \& Harvey, M.D. (eds): Recent developments in fluvial sedimentology. Society of Economic Paleontologists and Mineralogists Special Publication 39: 243-252.

Allen, J.R.L., 1964. Studies in fluviatile sedimentation: six cyclothems from the Lower Old Red Sandstone, Anglo-Welsh Basin. Sedimentology 3: 163-198.

Allen, J.R.L., 1965. A review of the origin and characteristics of recent alluvial sediments. Sedimentology 5: 89-191.

Allen, J.R.L., 1978. Studies in fluviatile sedimentation: an exploratory quantitative model for the architecture of avulsion-controlled alluvial suites. Sedimentary Geology 21: 129-147.

Allen, J.R.L., 1979. Studies in fluviatile sedimentation: an elementary model for the connectedness of avulsion-related channel sand bodies. Sedimentary Geology 24: 253-267.

Ashworth, P.J., Best, J.L. \& Jones, M., 2004. Relationship between sediment supply and avulsion frequency in braided rivers. Geology 32: 21-24.

Ashworth, P.J., Best, J.L. \& Jones, M.A., 2007. The relationship between channel avulsion, flow occupancy and aggradation in braided rivers: insights from an experimental model. Sedimentology 54: 497-513.

Aslan, A. \& Autin, W.J., 1999. Evolution of the Holocene Mississippi river floodplain, Ferriday, Louisiana: insights on the origin of fine-grained floodplains. Journal of Sedimentary Research 69: 800-815.

Aslan, A. \& Blum, M.D., 1999. Contrasting styles of Holocene avulsion, Texas Gulf Coastal Plain, USA. In: Smith, N.D. \& Rogers, J. (eds): Fluvial Sedimentology VI. Special Publication of the International Association of Sedimentologists 28: 193-209.

Aslan, A., Autin, W.J. \& Blum, M.D., 2005. Causes of river avulsion: insights from the Late Holocene avulsion history of the Mississippi River, USA. Journal of Sedimentary Research 75: 650-664.

Autin, W.J., Burns, S.F., Miller, B.J., Saucier, R.T. \& Snead, J.I., 1991. Quaternary geology of the Lower Mississippi Valley. In: Morrison, R.B. (ed.): Quaternary Nonglacial Geology: Conterminous U.S. Geological Survey of America, The Geology of North America K-2: 547-582.

Berendsen, H.J.A., 1982. De genese van het landschap in het zuiden van de provincie Utrecht: een fysisch-geografische studie. Published PhD Thesis Utrecht University. Utrechtse Geografische Studies 10: 256 pp.

Berendsen, H.J.A. \& Stouthamer, E., 2000. Late Weichselian and Holocene palaeogeography of the Rhine-Meuse delta, the Netherlands. Palaeogeography, Palaeoclimatology, Palaeoecology 161: 311-335.

Berendsen, H.J.A. \& Stouthamer, E., 2001. Palaeogeographic development of the Rhine-Meuse delta, the Netherlands. Koninklijke Van Gorcum (Assen): 268 pp.

Berendsen, H.J.A., Hoek, W.Z. \& Schorn, E.A., 1995. Late Weichselian and Holocene river channel changes of the rivers Rhine and Meuse in the Netherlands (Land van Maas en Waal). In: Frenzel, B. (ed.): European river activity and climate change during the Lateglacial and Holocene. ESF Project European Paläoklimaforschung. Palaeoclimate Research 14: 151-171.

Blum, M.D. \& Price, D.M., 1998. Quaternary alluvial plain construction in response to interacting glacio-eustatic and climatic controls, Texas Gulf Coast Plain. In: Shanley, K.W. \& McCabe, P.J. (eds): Relative role of Eustasy, Climate, and Tectonism in Continental Rocks. Society of Economic Paleontologists and Mineralogists Special Publication 59: 31-48.
Blum, M.D. \& Törnqvist, T.E., 2000. Fluvial responses to climate and sea-level change: a review and look forward. Sedimentology 47: 2-48.

Bridge, J.S., 1999. Alluvial architecture of the Mississippi valley: predictions using a 3D simulation model. In: Marriott, S.B. \& Alexander, J. (eds): Floodplains: Interdisciplinary Approaches. Geological Society of London, Special Publication 163: 269-278.

Bridge, J.S., 2003. Rivers and Floodplains; Forms, Processes, and Sedimentary Record. Blackwell Publishing (0xford): 491 pp.

Bridge, J.S. \& Karssenberg, D., 2005. Simulation of flow and sedimentary processes, including channel bifurcation and avulsion, on alluvial fans. (abstract). 8th International Conference on Fluvial Sedimentology, Delft, the Netherlands, Abstracts, Delft, p. 70.

Bridge, J.S. \& Leeder, M.R., 1979. A simulation model of alluvial stratigraphy. Sedimentology 26: 617-644.

Bridge, J.S. \& Mackey, S.D., 1993a. A revised alluvial stratigraphy model. In: Marzo, M. \& Puigdefabregas, C. (eds): Alluvial Sedimentation. Special Publication of the International Association of Sedimentologists 17: 319-336.

Bridge, J.S. \& Mackey, S.D., 1993b. A theoretical study of fluvial sandstone body dimensions. In: Flint, S. \& Bryant, I.D. (eds): The Geological Modeling of Hydrocarbon Reservoirs. International Association of Sedimentologists Special Publication 15: 213-236.

Bridge, J.S., Jalfin, G.A. \& Georgieff, S.M., 2000. Geometry, lithofacies, and spatial distribution of Cretaceous fluvial sandstone bodies, San Jorge Basin, Argentina: outcrop analog for the hydrocarbon-bearing Chubut Group. Journal of Sedimentary Research 70: 341-359.

Bryant, M., Falk, P. \& Paola, C., 1995. An experimental study of avulsion frequency and rate of deposition. Geology 23: 365-368.

Chappell, J., Omura, A., Ezat, T., McCulloch, M., Pandolfi, J., Ota, Y. \& Pillans, B., 1996. Reconciliation of late Quaternary sea-levels derived from coral terraces at Huon Peninsula with deep sea oxygen isotope records. Earth and Planetary Science Letters 141: 227-236.

Cohen, K.M., 2003. Differential subsidence within a coastal prism. Late-Glacial - Holocene tectonics in the Rhine-Meuse delta, the Netherlands. Published PhD Thesis Utrecht University. Netherlands Geographical Studies 316: 172 pp.

Cohen, K.M., 2005. 3D Geostatistical interpolation and geological interpretation of palaeo-groundwater rise in the Holocene coastal prism in the Netherlands. In: Giosan, L. \& Bhattacharya, J.P. (eds): River deltas - Concepts, models, and examples. SEPM Special Publication 83: 341-364.

Cohen, K.M., Stouthamer, E. \& Berendsen, H.J.A., 2002. Fluvial deposits as a record for Late Quaternary neotectonic activity in the Rhine-Meuse delta, the Netherlands. Netherlands Journal of Geosciences / Geologie en Mijnbouw 81: 389-405.

Cohen, K.M., Gouw, M.J.P. \& Holten, J.P., 2005. Fluvio-deltaic flood basin deposits recording differential subsidence within a coastal prism (central Rhine-Meuse delta, the Netherlands). In: Blum, M.D., Marriott, S.B. \& Leclair, S.F. (eds): Fluvial Sedimentology VII. Special Publication of the International Association of Sedimentologists 35: 295-320.

Collinson, J.D., 1978. Vertical sequence and sand body shape in alluvial sequences. In: Miall, A.D. (ed.): Fluvial Sedimentology. Canadian Society of Petroleum Geologists Memoir 5: 577-586. 
Farrell, K.M., 1987. Sedimentology and facies architecture of overbank deposits of the Mississippi River, False River region, Louisiana. In: Etheridge, F.G., Flores, R.M. \& Harvey, M.D. (eds): Recent Developments in Fluvial Sedimentology. Society of Economic Paleontologists and Mineralogists Special Publication 39: 111-120.

Farrell, K.M., 2001. Geomorphology, facies architecture, and high-resolution, non-marine sequence stratigraphy in avulsion deposits, Cumberland Marshes, Saskatchewan. Sedimentary Geology 139: 93-150.

Fielding, C.R. \& Crane, R.C., 1987. An application of statistical modeling to the prediction of hydrocarbon recovery factors in fluvial reservoir sequences. In: Etheridge, F.G., Flores, R.M., \& Harvey, M.D. (eds): Recent Developments in Fluvial Sedimentology. Society of Economic Paleontologists and Mineralogists Special Publication 39: 321-327.

Fisk, H.N., 1944. Geological investigation of the alluvial valley of the Lower Mississippi River. Mississippi River Commission (Vicksburg, Mississippi): 78 pp.

Fisk, H.N., 1947. Fine-grained alluvial deposits and their effects on Mississippi River activity. U.S. Army Corps of Engineers, Mississippi River Commission (Vicksburg, Mississippi): 82 pp.

Friend, P.F., 1983. Towards the field classification of alluvial architecture or sequence. In: Collinson, J.D. \& Lewin, J. (eds): Modern and Ancient Fluvial Systems. International Association of Sedimentologists Special Publication 6: 345-354.

Friend, P.F., Slater, M.J. \& Williams, R.C., 1979. Vertical and lateral building of river sandstone bodies, Ebro Basin, Spain. Geological Society of London Journal 136: 39-46.

Gibling, M.R., 2006. Width and thickness of fluvial channel bodies and valley fills in the geological record: a literature compilation and classification. Journal of Sedimentary Research 76: 731-770.

Gouw, M.J.P., in press. Alluvial architecture of the Holocene Rhine-Meuse delta (the Netherlands) and the Lower Mississippi Valley (U.S.A.). PhD Thesis Utrecht University. Netherlands Geographical Studies.

Gouw, M.J.P. \& Berendsen, H.J.A., 2007. Variability of channel-belt dimensions and the consequences for alluvial architecture: observations from the Holocene Rhine-Meuse delta (the Netherlands) and Lower Mississippi Valley (USA). Journal of Sedimentary Research 77: 124-138.

Gouw, M.J.P. \& Erkens, G., 2007. Architecture of the Holocene Rhine-Meuse delta (the Netherlands) - A result of changing external controls. In: Stouthamer, E. \& Ten Brinke, W. (eds): Fluvial Sedimentology. Netherlands Journal of Geosciences / Geologie en Mijnbouw 86: 23-54.

Heller, P.L. \& Paola, C., 1996. Downstream changes in alluvial architecture: an exploration of controls on channel-stacking pattern. Journal of Sedimentary Research 66: 297-306.

Holbrook, J. \& Schumm, S.A., 1999. Geomorphic and sedimentary response of rivers to tectonic deformation: a brief review and critique of a tool for recognizing subtle epeirogenic deformation in modern and ancient settings. Tectonophysics 305: 287-306.

Jelgersma, S., 1961. Holocene sea-level changes in the Netherlands. Published PhD Thesis University Leiden. Mededelingen Geologische Stichting CVI-1: $101 \mathrm{pp}$.

Jones, L.S. \& Schumm, S.A., 1999. Causes of avulsion: an overview. In: Smith, N.D. \& Rogers, J. (eds): Fluvial Sedimentology VI. Special Publication of the International Association of Sedimentologists 28: 171-178.
Karssenberg, D., Törnqvist, T.E. \& Bridge, J.S., 2001. Conditioning a processbased model of sedimentary architecture to well data. Journal of Sedimentary Research 71: 868-879.

Karssenberg, D. \& Bridge, J.S., 2005. A 3D model simulating sediment transport, erosion, and deposition within a network of channel belts and an associated floodplain. (abstract). 8th International Conference on Fluvial Sedimentology, Delft, the Netherlands, Abstracts, Delft, p. 151.

Karssenberg, D. \& Bridge, J.S., in review. A three-dimensional model of sediment transport, erosion, and deposition within a network of channel belts, floodplain and hillslope: extrinsic and intrinsic controls on floodplain dynamics and alluvial architecture. Submitted to Sedimentology.

Kolb, C.R. \& Van Lopik, J.R., 1958. Geology of the Mississippi River deltaic plain, southeastern Louisiana. Technical Report 3-483, U.S. Army Corps of Engineers, Mississippi River Commission (Vicksburg, Mississippi): 120 pp.

Kolb, C.R., Steinriede, W.B., Krinitzsky, E.L., Saucier, R.T., Mabrey, P.R., Smith, F.L. \& Fleetwood, A.R., 1968. Geological investigation of the Yazoo Basin, Lower Mississippi Valley. Technical Report 3-480, U.S. Army Corps of Engineers, Mississippi River Commission (Vicksburg, Mississippi): 12 pp.

Kombrink, H., Bridge, J.S. \& Stouthamer, E., 2007. The alluvial architecture of the Coevorden Field (Upper Carboniferous), the Netherlands. In: Stouthamer, E. \& Ten Brinke, W. (eds): Fluvial Sedimentology. Netherlands Journal of Geosciences / Geologie en Mijnbouw 86: 3-14.

Leeder, M.R., 1978. A quantitative stratigraphic model for alluvium, with special reference to channel deposit density and interconnectedness. In: Miall, A.D. (ed.): Fluvial Sedimentology. Canadian Society of Petroleum Geologists Memoir 5: 587-596.

Leeder, M.R., 1993. Tectonic controls upon drainage basin development, river channel migration and alluvial architecture: implications for hydrocarbon reservoir development and characterization. In: North, C.P. \& Prosser, D.J. (eds): Characterization of Fluvial and Aeolian Reservoirs. Geological Society of London Special Publication 73: 7-22.

Leopold, L.B. \& Wolman, M.G., 1957. River channel patterns: braided, meandering and straight. Geological Survey Professional Paper 282-B: 283-300.

Lopez, S., Cojan, I. \& Rivoirard et Galli, A., in press. Process-based stochastic modeling: meandering channelized reservoirs. To be published in: De Boer, P.L., Postma, G., Van der Zwan, C.J., Burgess, P.M. \& Kukla, P. (eds): Analogue and Numerical Forward Modeling of Sedimentary Systems; From Understanding to Prediction. International Association of Sedimentologists Special Publication 39.

Mackey, S.D. \& Bridge, J.S., 1995. Three-dimensional model of alluvial stratigraphy: theory and application. Journal of Sedimentary Research 65: 7-31.

Makaske, B., 1998. Anastomosing rivers: forms, processes and sediments. Published PhD Thesis Utrecht University. Netherlands Geographical Studies 249: $287 \mathrm{pp}$.

Makaske, B., 2001. Anastomosing rivers; a review of their classification, origin and sedimentary products. Earth-Science Reviews 53: 149-196.

Makaske, B., Smith, D.G. \& Berendsen, H.J.A., 2002. Avulsions, channel evolution and floodplain sedimentation rates of the anastomosing upper Columbia River, British Columbia, Canada. Sedimentology 49: 1049-1071.

Makaske, B., Berendsen, H.J.A. \& Van Ree, M.H.M., 2007. Middle Holocene avulsion-belt deposits in the central Rhine-Meuse delta, the Netherlands. Journal of Sedimentary Research 77: 110-123. 
Meckel, T.A., Ten Brink, U.S. \& Williams, S.J., 2007. Sediment compaction rates and subsidence in deltaic plains: numerical constraints and stratigraphic influences. Basin Research 19: 19-31.

Mohrig, D., Heller, P.L., Paola, C. \& Lyons, W.J., 2000. Interpreting avulsion process from ancient alluvial sequences: Guadalope-Matarranya system (northern Spain) and Wasatch Formation (western Colorado). Geological Society of America Bulletin 112: 1787-1803.

Morozova, G.S. \& Smith, N.D., 1999. Holocene avulsion history of the lower Saskatchewan fluvial system, Cumberland Marshes, Saskatchewan-Manitoba, Canada. Special Publication of the International Association of Sedimentologists 28: 231-249.

Morozova, G.S. \& Smith, N.D., 2003. Organic matter deposition in the Saskatchewan River floodplain (Cumberland Marshes, Canada): effects of progradational avulsions. Sedimentary Geology 157: 15-29.

Nadon, G.C., 1994. The genesis and recognition of anastomosed fluvial deposits: data from the St. Mary River Formation, southwestern Alberta, Canada. Journal of Sedimentary Research 64: 451-463.

Paola, C., 2000. Quantitative models of sedimentary basin filling. Sedimentology 47 (Suppl. 1): 121-178.

Pérez-Arlucea, M. \& Smith, N.D., 1999. Depositional patterns following the 1870s avulsion of the Saskatchewan River (Cumberland Marshes, Saskatchewan, Canada). Journal of Sedimentary Research 69: 62-73.

Pizzuto, J.E., 1987. Sediment diffusion during overbank flows. Sedimentology 34: 301-317.

Pons, L.J., 1957. De geologie, de bodemvorming en de waterstaatkundige ontwikkeling van het Land van Maas en Waal en een gedeelte van het Rijk van Nijmegen. PhD Thesis Wageningen. Bodemkundige Studies 3. Verslagen van Landbouwkundige Onderzoekingen 63.11 ('s-Gravenhage): 156 pp.

Ryseth, A. \& Ramm, M., 1996. Alluvial architecture and differential subsidence in the Statfjord Formation, North Sea: prediction of reservoir potential. Petroleum Geoscience 2: 271-287.

Ryseth, A., Fjellbirkeland, H., Kloster Osmundsen, I., Skålnes, Å. \& Zachariassen, E., 1998. High-resolution stratigraphy and seismic attribute mapping of a fluvial reservoir: Middle Jurassic Ness Formation, Oseberg Field. American Association of Petroleum Geologists Bulletin 82: 1627-1651.

Saucier, R.T., 1994. Geomorphology and Quaternary geologic history of the Lower Mississippi Valley. 2 Volumes. U.S. Army Corps of Engineers Waterways Experiment Station, Mississippi River Commission (Vicksburg, Mississippi): $364 \mathrm{pp}$.

Schumm, S.A., 1968. Speculations concerning paleohydrologic controls of terrestrial sedimentation. Geological Society of America Bulletin 79: 1573-1588.

Schumm, S.A., Rutherford, I.D. \& Brooks, J., 1994. Pre-cutoff morphology of the Lower Mississippi River. In: Schumm, S.A. \& Winkley, B.R. (eds): The Variability of Large Alluvial Rivers. American Society of Civil Engineers Press (New York): 13-45.

Shanley, K.W. \& McCabe, P.J., 1993. Alluvial architecture in a sequence stratigraphic framework: a case history from the Upper Cretaceous of southern Utah, USA. International Association of Sedimentologists Special Publication 15: 21-56.

Slingerland, R. \& Smith, N.D., 1998. Necessary conditions for a meanderingriver avulsion. Geology 26: 435-438.

Slingerland, R. \& Smith, N.D., 2004. River avulsions and their deposits. Annual Review of Earth and Planetary Sciences 32: 257-285.
Smith, N.D. \& Pérez-Arlucea, M., 1994. Fine-grained splay deposition in the avulsion belt of the Lower Saskatchewan River, Canada. Journal of Sedimentary Research 64: 159-168.

Smith, N.D., Cross, T.A., Dufficy, J.P. \& Clough, S.R., 1989. Anatomy of an avulsion. Sedimentology 36: 1-23.

Smith, N.D., Slingerland, R.L., Pérez-Arlucea, M. \& Morozova, G.S., 1998. The 1870s avulsion of Saskatchewan River. Canadian Journal of Earth Sciences 35: 453-466.

Stanley, D.J. \& Warne, A.G., 1994. Worldwide initiation of Holocene marine deltas by deceleration of sea-level rise. Science 265: 228-231.

Stouthamer, E., 2001a. Holocene avulsions in the Rhine-Meuse delta, the Netherlands. Published PhD Thesis Utrecht University. Netherlands Geographical Studies 283: 211 pp.

Stouthamer, E., 2001b. Sedimentary products of avulsions in the Holocene Rhine-Meuse Delta, the Netherlands. Sedimentary Geology 145: 73-92.

Stouthamer, E., 2005. Reoccupation of channel belts and its influence on alluvial architecture in the Holocene Rhine-Meuse delta, the Netherlands. In: Giosan, L. \& Bhattacharya, J.P. (eds): River deltas - Concepts, models, and examples. SEPM Special Publication 83: 319-339.

Stouthamer, E. \& Berendsen, H.J.A., 2000. Factors controlling the Holocene avulsion history of the Rhine-Meuse delta (the Netherlands). Journal of Sedimentary Research 70: 1051-1064.

Stouthamer, E. \& Berendsen, H.J.A., 2001. Avulsion frequency, avulsion duration, and interavulsion period of Holocene channel belts in the RhineMeuse delta, the Netherlands. Journal of Sedimentary Research 71: 589-598.

Stouthamer, E. \& Berendsen, H.J.A., 2007. Avulsion: The relative roles of autogenic and allogenic processes. Sedimentary Geology 198: 309-325.

Swenson, J.B., 2005. Relative importance of fluvial input and wave energy in controlling the timescale for distributary-channel avulsion. Geophysical Research Letters 32: L23404, doi:10.1029/2005GL024758.

Törnqvist, T.E., 1993a. Fluvial sedimentary geology and chronology of the Holocene Rhine-Meuse delta, the Netherlands. Published PhD Thesis Utrecht University. Netherlands Geographical Studies 166: 169 pp.

Törnqvist, T.E., 1993b. Holocene alternation of meandering and anastomosing fluvial systems in the Rhine-Meuse delta (central Netherlands) controlled by sea-level rise and subsoil erodibility. Journal of Sedimentary Petrology 63: 683-693.

Törnqvist, T.E., 1994. Middle and Late Holocene avulsion history of the River Rhine (Rhine-Meuse delta, the Netherlands). Geology 22: 711-714.

Törnqvist, T.E. \& Bridge, J.S., 2002. Spatial variation of overbank aggradation rate and its influence on avulsion frequency. Sedimentology 49: 891-905.

Törnqvist, T.E., Van Ree, M.H.M. \& Faessen, E.L.J.H., 1993. Longitudinal facies architectural changes of a Middle Holocene anastomosing distributary system (Rhine-Meuse delta, central Netherlands). In: Fielding, C.R. (ed.): Current Research in Fluvial Sedimentology. Sedimentary Geology 85: 203219.

Törnqvist, T.E., Kidder, T.R., Autin, W.J., Van der Borg, K., De Jong, A.F.M., Klerks, C.J.W., Snijders, E.M.A., Storms, J.E.A., Van Dam, R.L. \& Wiemann, M.C., 1996. A revised chronology for Mississippi River Subdeltas. Science 273: 1693-1696. 
Tye, R.S., Bhattacharya, J.P., Lorsong, J.A., Sindelar, S.T., Knock, D.G., Puls D.D. \& Levinson, R.A., 1999. Geology and stratigraphy of fluvio-deltaic deposits in the Ivishak Formation; applications for development of Prudhoe Bay Field, Alaska. American Association of Petroleum Geologists Bulletin 83: 1588-1623.

Vandenberghe, J., 1995. Timescales, climate and river development. Quaternary Science Reviews 14: 631-638.

Van de Plassche, 0., 1982. Sea-level change and water level movements in the Netherlands during the Holocene. Mededelingen Rijks Geologische Dienst 36: $93 \mathrm{pp}$.

Van der Woude, J.D., 1984. The fluviolagoonal palaeoenvironment in the Rhine/ Meuse deltaic plain. Sedimentology 31: 395-400.

Van Dijk, G.J., Berendsen, H.J.A. \& Roeleveld, W., 1991. Holocene water level development in the Netherlands river area: implications for sea-level reconstruction. Geologie en Mijnbouw 70: 311-326.

Weerts, H.J.T., 1996. Complex Confining Layers. Architecture and hydraulic properties of Holocene and Late Weichselian deposits in the fluvial RhineMeuse delta, the Netherlands. Published PhD Thesis Utrecht University. Netherlands Geographical Studies 213: 189 pp.

Weerts, H.J.T. \& Bierkens, M.F.P., 1993. Geostatistical analysis of overbank deposits of anastomosing and meandering fluvial systems; Rhine-Meuse delta, the Netherlands. In: Fielding, C.R. (ed.): Current Research in Fluvial Sedimentology. Sedimentary Geology 85: 221-232

Williams, G.P., 1986. River meanders and channel size. Journal of Hydrology 88: 147-164.

Wolfert, H.P., 2001. Geomorphological change and river rehabilitation; case studies on lowland fluvial systems in the Netherlands. Published PhD Thesis Utrecht University. Alterra Scientific Contributions 6: 200 pp. 